Review

\title{
Neutrophil Recruitment and Participation in Severe Diseases Caused by Flavivirus Infection
}

\author{
Marina Alves Fontoura ${ }^{1,2} \mathbb{D}$, Rebeca Fróes Rocha ${ }^{1,3,4}$ and Rafael Elias Marques ${ }^{1, *(D)}$ \\ 1 Brazilian Biosciences National Laboratory_LNBio, Brazilian Center for Research in Energy and \\ Materials-CNPEM, Campinas 13083-100, Brazil; marina.fontoura@Inbio.cnpem.br (M.A.F.); \\ rebeca.rocha@lnbio.cnpem.br (R.F.R.) \\ 2 Cellular and Structural Biology Graduate Program, Institute of Biology, University of Campinas (UNICAMP), \\ Campinas 13083-865, Brazil \\ 3 Genetics and Molecular Biology Graduate Program, Institute of Biology, \\ University of Campinas (UNICAMP), Campinas 13083-970, Brazil \\ 4 Department of Integrative Structural and Computational Biology, The Scripps Research Institute, \\ La Jolla, CA 92037, USA \\ * Correspondence: rafael.marques@lnbio.cnpem.br
}

Citation: Fontoura, M.A.; Rocha, R.F.; Marques, R.E. Neutrophil Recruitment and Participation in Severe Diseases Caused by Flavivirus Infection. Life 2021, 11, 717. https: / / doi.org/10.3390/life11070717

Academic Editors: Olga

M. Koper-Lenkiewicz,

Violetta Dymicka-Piekarska and Joanna Kamińska

Received: 21 June 2021

Accepted: 19 July 2021

Published: 20 July 2021

Publisher's Note: MDPI stays neutral with regard to jurisdictional claims in published maps and institutional affiliations.

Copyright: (c) 2021 by the authors. Licensee MDPI, Basel, Switzerland. This article is an open access article distributed under the terms and conditions of the Creative Commons Attribution (CC BY) license (https:/ / creativecommons.org/licenses/by/ $4.0 /)$.
Abstract: Neutrophils are first-line responders to infections and are recruited to target tissues through the action of chemoattractant molecules, such as chemokines. Neutrophils are crucial for the control of bacterial and fungal infections, but their role in the context of viral infections has been understudied. Flaviviruses are important human viral pathogens transmitted by arthropods. Infection with a flavivirus may result in a variety of complex disease manifestations, including hemorrhagic fever, encephalitis or congenital malformations. Our understanding of flaviviral diseases is incomplete, and so is the role of neutrophils in such diseases. Here we present a comprehensive overview on the participation of neutrophils in severe disease forms evolving from flavivirus infection, focusing on the role of chemokines and their receptors as main drivers of neutrophil function. Neutrophil activation during viral infection was shown to interfere in viral replication through effector functions, but the resulting inflammation is significant and may be detrimental to the host. For congenital infections in humans, neutrophil recruitment mediated by CXCL8 would be catastrophic. Evidence suggests that control of neutrophil recruitment to flavivirus-infected tissues may reduce immunopathology in experimental models and patients, with minimal loss to viral clearance. Further investigation on the roles of neutrophils in flaviviral infections may reveal unappreciated functions of this leukocyte population while increasing our understanding of flaviviral disease pathogenesis in its multiple forms.

Keywords: neutrophils; flavivirus; encephalitis; hemorrhagic fever; pregnancy

\section{Flaviviruses}

Flaviviruses are a group of arthropod-borne viruses composing the Flavivirus genus (Flaviviridae family). Flaviviruses are positive-sense, single-stranded, enveloped RNA viruses known to cause widespread morbidity and mortality throughout the world [1]. Most flaviviral infections are asymptomatic or may present with flu-like symptoms. A small proportion of patients may develop severe forms of disease vary with the etiological agent: Dengue and Yellow fever viruses (DENV, YFV) may cause hemorrhagic fever and shock [2]; Japanese encephalitis virus (JEV), West Nile virus (WNV) and St. Louis Encephalitis virus (SLEV) may cause meningoencephalitis [3]; and Zika virus (ZIKV) may cause teratogenesis in pregnant women and Guillain-Barré syndrome in male and female adults [4]. Although severe disease manifestations following infection with hemorrhagic or encephalitogenic flaviviruses, or Zika, are considerably different, they all share a common proinflammatory component manifested in target tissues.

Most flaviviruses are neglected in terms of investment in research and development and public awareness. Between October 2011 and July 2012, a study conducted in the 
state of Mato Grosso, Brazil, collected sera from patients presenting with acute febrile illness. The study identified, during a large dengue outbreak, that 12 out of 15 patients positive for DENV-4 RNA were also positive for Mayaro virus (MAYV) RNA, an unrelated alphavirus [5]. Another example of silent circulation of strains happened in Italy 2008, where 5 WNV-positive patients also presented Usutu virus (USUV) neutralizing antibodies [6]. Most flaviviruses lack commercially available means for disease diagnosis, specific treatments and vaccines. This situation often results in underestimated rates of infection and high rates of morbidity and mortality in affected populations, especially during outbreaks $[7,8]$.

\section{Neutrophils and Their Effector Functions}

Neutrophils are polymorphonuclear (PMN) leukocytes, also known as neutrophilic granulocytes, which are multifaceted effector cells of the innate immune system. Neutrophils are characterized by their capacity to phagocytose a variety of objects and are specialized in engulfing and destroying pathogens (such as bacteria and fungi) and cellular debris. Despite being a heterogeneous population, neutrophils present a typical multilobed nucleus with condensed chromatin, suggestive of reduced transcriptional activity. Neutrophils originate in the bone marrow and bear numerous granules and secretory vesicles in its cytoplasm, hence granulocytes, loaded with proteases, reactive oxygen species (ROS) and several effector molecules that are involved in neutrophilic microbicidal activity [9]. Neutrophils are capable of activation, differentiation and interaction with other leukocyte populations and non-immune cells, and express a variety of receptors at the cellular surface and may secrete cytokines and proinflammatory mediators upon stimuli. Those features allow neutrophils to lead and exert considerable influence on the course of an immune response against a pathogen [10].

Neutrophils are the first leukocytes recruited to the infected or inflamed tissue. When activated by chemotactic molecules, neutrophils are recruited to tissues and perform antimicrobial and proinflammatory functions. The coordinated recruitment of neutrophils to the site of injury or inflammation might be amplified by positive-feedback loops of chemotactic signals, leading to a focal accumulation of PMNs called neutrophil swarming $[11,12]$. Neutrophil recruitment is induced by different chemoattractant molecules from various sources and compositions: N-formylated peptides, C3a and C5a from complement, lipid mediators such as leukotriene B4 and chemokines [13]. Accordingly, neutrophil recruitment is mediated by different receptors recognizing formyl-peptides, complement, leukotrienes and chemokines, which are all present on the neutrophil surface in physiological conditions [14]. Although chemoattractant receptors expressed by neutrophils interact with different classes of ligands, all receptors are seven-transmembrane $G$ protein-coupled receptors (GPCRs) triggering neutrophil chemotaxis through related mechanisms. The CXC class of chemokines presenting a glutamate-leucine-arginine motif (ELR) are major inducers of neutrophil recruitment and activation [15]. Chemokine ligands CXCL1, CXCL2, CXCL3, CXCL5 and CXCL8 (in humans) bind to CXCR1 and CXCR2 receptors in human neutrophils while their orthologues bind to CXCR2 in mice. Most chemokines without ELR motif (such as CXCL4, CXCL9-11) bind to CXCR3 receptors, while CXCL12 is the only known ligand for CXCR4 [16].

Although neutrophils are short-lived cells known to have limited transcriptional activity, they express many cell surface receptors that recognize microbial patterns and proinflammatory mediators such as: innate immunity pattern-recognition receptors (PRR), cytokine receptors, Fc-receptors, chemokine receptors and adhesion molecules [14]. When stimulated, neutrophils may express chemokines, cytokines and lipid mediators [17,18]. Detection of invading pathogens through microbial PRRs triggers an antimicrobial response in neutrophils, in which phagocytosis plays a major role in restriction and elimination of infection. Phagocytic mechanisms are most effective on opsonized pathogens, which may take place by action of complement, antibodies and lectins. Surface expression of Fc-receptors, complement receptors and other classes of binding receptors are critical for neutrophilic 
effector functions and the control of pathogen replication. Moreover, CCL2 and CXCL10 chemokines were reported to mediate oxidative stress-induced neutrophilic inflammation in lungs [19]. The ability of neutrophils to eliminate pathogens, once phagocytosed, is directly associated with production of ROS. The nicotinamide adenine dinucleotide phosphate (NADPH) oxidase 2 (NOX2) enzyme is responsible for ROS production in neutrophils, which are released onto internalized pathogens and result in microorganism destruction [20].

Degranulation is a well-characterized effector mechanism of neutrophils and essential for their ability to fulfill their role in innate immunity [21]. At the end of the 19th century, Paul Ehrlich described two major kinds of lysozyme-carrying granules in PMN cells, the azurophilic and the specific granules. Azurophilic granules (also known as peroxidasepositive granules) are rich in mucopolysaccharide, elastase, matrix metalloproteinases, defensins and myeloperoxidase (MPO) [22,23]. Peroxidase-negative granules are loaded with varying levels of lactoferrin, an iron-binding protein participating in neutrophil adhesion and survival [24,25], as well as gelatinase, which facilitates neutrophil infiltration into the tissue [26]. When undergoing exocytosis, granule content is released and transmembrane proteins in granules are translocated to the cell surface [27].

Neutrophils are able to release their DNA into the interstitium forming a molecular complex called Neutrophil extracellular traps (NETs) [28]. NETs are networks of DNA conjugated to antimicrobial enzymes such as myeloperoxidase (MPO), elastases and histones, which can capture and kill pathogens, including viruses [28-31]. NETosis, the process of cellular death that leads to NET formation begins with the activation of neutrophils by PRRs, followed by the production of ROS and mobilization of cytosolic calcium [28]. Release of NETs depends on the activation of the protein-arginine deiminase 4 (PAD4) enzyme, which citrullinates histones $\mathrm{H} 3$ and $\mathrm{H} 4$ causing decondensation of chromatin. DNA in the neutrophil nucleus is mixed with contents from azurophilic granules and released in the cytoplasm, followed by lysis of the plasma membrane and release of NETs to the extracellular environment. Once released, NETs have an important role in containment and elimination of bacteria, fungi and viruses, but may also cause significant tissue damage [32-34]. Systemic inflammation and organ damage observed in mouse models of severe sepsis are correlated with neutrophil recruitment to tissues and with release of NETs. The inhibition of NET production using a NOX2 inhibitor or its degradation with DNase prevents injuries, increasing septic mouse survival up to $90 \%$. In accordance, the levels of NETs were increased in the serum of septic patients and the levels were correlated with the scores of organ lesions studied $[29,30]$.

After neutrophil effector functions are carried out, neutrophil-induced inflammation enters a resolution phase. The resolution of inflammation is actively mediated by leukocytes, receptors and soluble effectors, resulting in neutrophil apoptosis and clearance of apoptotic debris by macrophages, triggering the release of proresolving lipid mediators and cytokines [35]. Phagocytosis of apoptotic neutrophils reduces IL-23 production and therefore inhibits neutrophil production/release from bone marrow, ensuring homeostatic stability of the number of neutrophils in circulation [36]. Failure of this process likely contributes to chronic inflammation while release of proresolving mediators limit acute inflammation and restore normal tissue homeostasis [37].

\section{Participation of Neutrophils in Immune Responses against Viruses}

The innate immune response against viral infections starts with viral recognition by PRRs such as those from Toll-like receptor (TLR), C-type Lectin or DExD/H box RNA helicase families. These cellular sensors are present in several cell types besides neutrophils, especially in antigen presenting cells (APC) such as dendritic cells and macrophages [38]. Activation of PRRs recognizing viral DNA or RNA leads to engagement of signaling pathways leading to activation of IRF transcriptional factors and the production of type-I interferons (IFNs) and proinflammatory cytokines. Type-I IFNs act in an autocrine and paracrine way, binding to the type-I IFN receptor IFNAR and upregulating the expression 
of interferon stimulated genes (ISG) that culminate in an antiviral state incompatible with viral replication and dissemination. Thus, a transient or partial inhibition of interferon responses is a prerequisite for viral replication and the establishment of infection [39-41]. Viruses have evolved several molecular mechanisms to evade the host's IFN responses including the inhibition of signaling pathways, ISG function and direct antagonism of type-I IFNs. Murine neutrophils exposed to IFN- $\lambda$ (a type-III IFN) can express ISGs; and IFN- $\lambda$ (but not IFN- $\beta$ ) specifically activated a translation-independent signaling pathway that reduced ROS production and degranulation in neutrophils, which was associated to control of the inflammatory process [42].

Neutrophils are able to internalize viruses bound to antibodies or opsonized by complement, and express PRRs such as TLR7, TLR8 and MDA5 that would be activated upon binding of viral genomes, depending on genome composition and structure [41]. Neutrophils are not target cells in the majority of viral infections, being either impervious to infection or nonpermissive of viral replication $[29,43]$. Few exceptions include the infection of neutrophils by alphavirus and evidence that hepatitis $C$ virus can replicate in PMN cells [44], but the contribution of this event to viremia and disease development is unknown. Results obtained from in-vivo experimental models of viral infections are biased towards inherent characteristics of both host and methods and should always be considered in data interpretation before inferences on the role of neutrophils in viral infections in humans. For example, murine neutrophils are not susceptible to many human viruses such as IAV and alphaviruses $[45,46]$, while human neutrophils have been reported to be infected by these viruses and others such as Marburg virus, Respiratory Syncytial virus (RSV) and Epstein-Barr virus [47-51].

Neutrophils are the main leukocyte population recruited to the respiratory tract during respiratory virus infections. Neutrophil recruitment and activation are beneficial to hosts infected with Influenza A virus (IAV), in which neutrophils contribute to recruitment of other leukocyte populations and to viral clearance. IAV directly binds to neutrophils through sialylated glycoproteins and glycolipids present on the plasma membrane, leading to the production of $\mathrm{H}_{2} \mathrm{O}_{2}[52,53]$. Neutrophil production of proinflammatory cytokines such as interleukin-1 $\beta$ (IL-1 $\beta$ ) and tumor necrosis factor- $\alpha$ (TNF- $\alpha)$, along with the release of ROS and other cytotoxic molecules, are important in initial phases of disease but may cause damage and tissue necrosis if uncontrolled [54,55]. Moreover, neutrophils are often involved in containing secondary bacterial infections associated with respiratory viral infections [56].

Patients with Influenza showed increased levels of CXCL8, IFN- $\alpha$, TNF- $\alpha$ and IL-10 in plasma and/or nasal washes [57-59] and complement C5a in blood [60]. Studies of IAV infection in mice show that blockade of $\mathrm{C} 5$ a minimized neutrophil recruitment to lungs and tissue injury [61] and blockade of IL-1 $\beta$ and IL-6 resulted in decreased neutrophil activation and chemotaxis to lungs $[62,63]$. RSV, Pneumonia virus (PVM) and IAV infections promote oxidative burst in murine neutrophils $[56,64,65]$. Complement and Fc $\gamma$ Rs receptors present in neutrophils recognize opsonized pathogens and trigger neutrophil effector functions. For example, in RSV and IAV infections, viral particles can be opsonized by surfactant protein D, facilitating neutrophil phagocytosis. Phagocytosis promotes ROS production $[66,67]$ and fusion of cytoplasmic granules rich in hydrolytic enzymes and NADPH oxidase with the phagosome [68], where the pathogen can be destroyed. ROS production has been shown to inhibit the mammalian target of rapamycin (mTOR) kinase, triggering an antiviral response against CMV [69,70]. Furthermore, neutrophil-derived ROS promote autophagy and cell death in cellular reservoirs, which in turn are phagocytosed by neutrophils, leading to resolution of inflammation [71].

Patients suffering from chronic viral hepatitis can develop various extra-hepatic disorders, affecting the blood, kidneys and lungs, which likely involves neutrophils. The total leukocyte and neutrophil counts in the bronchoalveolar lavage fluid of patients with chronic hepatitis $C$ were significantly greater than those of healthy controls [72]. In a separate study with chronic hepatitis $C$ patients, impaired neutrophil phagocytosis and 
mild hemolysis were observed in patients with and without cirrhosis. Direct acting antiviral therapy restored neutrophil function irrespective of severity of liver disease, suggesting that neutrophil dysfunction was related to HCV replication in the liver [73]. TREM1 (Triggering Receptor Expressed on myeloid cells 1) is a proinflammatory receptor expressed by phagocytes whose soluble form is increased in patients suffering from hepatitis B or C. Lymphocytic Choriomeningitis virus (LCMV) infection is used as a model for viral hepatitis in mice and Trem1-deficient mice infected with LCMV present an attenuated form of hepatitis. Neutrophils were found to express TREM1 and were recruited to the infected liver and absence of TREM1 resulted in reduced levels of CCL2 and TNF- $\alpha$ and less immunopathology without compromising the antiviral response [74].

Recent studies have pointed out that viral pathogen-associated molecular patterns (PAMPs) induce the release of NETs, which have been associated with protection from infection. In-vitro and in-vivo studies have both demonstrated that the sticky, web-like structure of NETs can bind and sequester virions, reducing viral load and improving survival in vivo [34]. NETosis is observed in viral infections by RSV, HIV-1, CHIKV, and SARS-CoV-2 [31-33,75,76] and contributes to tissue damage. DNA in NETs is critical for virus sequestration, and NETs efficacy was compromised following treatment with DNase. Pentraxin 3 (PTX3) is a soluble PRR produced by several cells, including macrophages and neutrophils. Recent studies have shown that PTX3 is produced and stored in neutrophilspecific granules and released together with NETs. The mechanisms behind the functions of PTX3 in association with NETs are unclear, as the roles of PTX3 in the neutrophilic response to viral infections [77]. Moreover, MPO and $\alpha$-defensins have also been found to be associated with NETs, where they would contribute to virus inactivation [78].

\section{Participation of Neutrophils and Neutrophil-Associated Molecules in Flaviviral Diseases}

\subsection{Hemorrhagic Fevers}

Viral hemorrhagic fevers (VHF) are a group of illnesses that affect multiple organ systems and are characterized by high fever, increased vascular permeability, decreased plasma volume, coagulation abnormalities, shock and hemorrhage [79]. Four different RNA viral families are known to cause VHF including Arenaviridae, Bunyaviridae, Filoviridae and Flaviviridae. Different viruses with different invading strategies and disease mechanisms can lead to VHF. Despite those differences, the severity of these individual diseases roughly correlates with the onset of vascular pathologies [80].

YFV and DENV are two flaviviruses known to cause VHF. Both viruses are mainly transmitted by Aedes aegypti mosquitoes and can be maintained in a sylvatic, enzootic cycle [81]. The mosquito saliva contains molecules known to modulate host inflammation, increasing cell susceptibility to the viruses. It is suggested that mosquito bite enhancement of virus infection is not related to interferon response suppression. Instead, host increased susceptibility is closely related to neutrophil-dependent inflammation after a bite [82,83]. Following a bite, mast cell degranulation markedly increases the expression of IL-1 $\beta$, IL-6 and neutrophil-attracting chemokines such as CXCL1, CXCL2, CXCL3 and CXCL5. Neutrophils are recruited to the site and express high levels of IL-1 $\beta$, which orchestrates the local inflammatory environment by leading to the recruitment of myeloid cells, a primary target cell for flaviviruses [83] (Figure 1). 


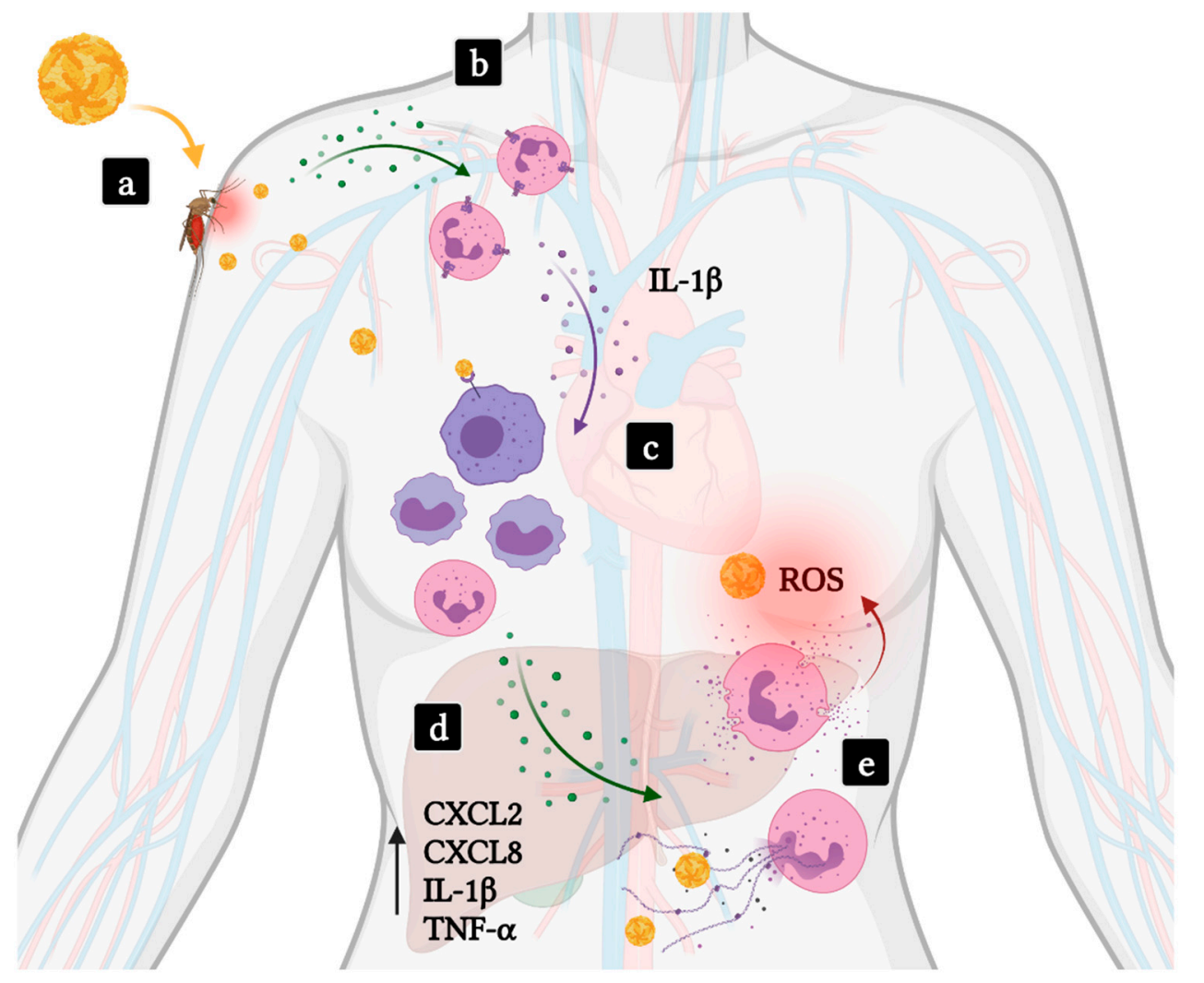

Figure 1. Involvement of neutrophils in hemorrhagic fever and shock induced by flavivirus infections. (a) Viruses such as DENV or YFV (yellow viral particles) are transmitted to human hosts through an infected mosquito bite. (b) Local inflammation results in the recruitment of neutrophils to the infected site. (c) Activated neutrophils amplify inflammation secreting IL-1 $\beta$. Subsequent activation and recruitment of mononuclear phagocytic leukocytes, target cells in flavivirus infections, promotes viral replication and dissemination of infection. (d) Severe disease takes place as high levels of proinflammatory cytokines are produced, including those participating in neutrophil recruitment and activation, and result in systemic inflammation and multiorgan failure. (e) Levels of ROS and MPO-DNA complexes correlate with disease severity. Green dots-Neutrophil chemoattractants; Purple dots-IL-1 $\beta$.

A common underlying mechanism in VHF is a massive production of proinflammatory cytokines. High levels of cytokines such as CXCL2, CXCL8, IL-6, TNF- $\alpha$ are usually found in the blood of severe yellow fever and dengue fever patients $[84,85]$. The role of neutrophils in severe YFV infection is unclear. However, similar to what is observed in severe DENV infections, levels of CCL2, IL-1 $\beta$, IL-1Ra and TNF- $\alpha$ are increased [86]. Recent evidence supports the involvement of neutrophils in the pathogenesis of severe dengue fever $[87,88]$. Given the similarities between the inflammatory pathways triggered in severe cases of Dengue and Yellow fever, neutrophils may also play an important role in YFV pathogenesis. CXCL2, CXCL8, IL-1 $\beta$ and TNF- $\alpha$ participate either in neutrophil recruitment or activation, and more studies are needed to better characterize the relationship between neutrophils and disease severity.

By comparing the transcriptional signatures of patients with early, severe and mild dengue symptoms, Hoang et al. showed that a major difference exists in the abundance of neutrophil-associated transcripts in humans [89]. Another study has shown an increase in the levels of elastase activity and other NETs components in Dengue hemorrhagic fever patients (DHF) when compared to patients presenting with mild disease, suggesting an association between neutrophil activation with disease severity. DENV infection leads to the production of CXCL8 and TNF- $\alpha$ which activates neutrophils leading to an upregulation of CD66b and increased production of ROS. Interestingly, increased levels of MPO-DNA complexes, major components of NETs, were found in the serum of DHF patients when compared with levels in dengue fever patients. Further, authors showed that DENV- 
primed neutrophils were prone to delobulation, an early feature of NET formation [88]. Further supporting the relevance of NET formation and severe dengue manifestation, in-vivo studies have shown encapsulation of platelets expressing dengue viral antigen by the NETs. Authors proposed that neutropenia, a common clinical sign in dengue patients, may be beneficial to the host, as components of NETs may aggravate dengue immunopathogenesis [90].

Overall, neutrophil recruitment during viral inoculation by Aedes aegypti mosquitoes seems to play a major role in early phases of infection. Further, patients with worse dengue disease outcomes present with increased neutrophil-associated transcripts along with upregulation of granulocyte activation markers, NET formation and ROS production. Similarities between proinflammatory cytokine plasma levels in both severe Dengue and Yellow fever patients indicate that the role of neutrophils should be investigated in yellow fever.

\subsection{Encephalitis}

Encephalitis is characterized by inflammation of the brain. Encephalitis may evolve from infection with neurotropic mosquito-borne flaviviruses such as JEV, WNV, SLEV and Murray Valley encephalitis virus (MVEV) or from Tick-borne encephalitis virus (TBEV) [91]. Upon the bite by a hematophagous arthropod vector, neurotropic flaviviruses are released in the skin, interact with resident mononuclear phagocytes and propagate to the draining lymph nodes, where other leukocytes become subsequently infected. Through mechanisms that have not yet been completely elucidated, neurotropic flaviviruses invade the central nervous system (CNS), infecting and activating cells, which culminates in encephalitis [92,93]. JEV alone results in approximately 60,000 deaths every year, most of which are children [94]. WNV and SLEV are reported more frequently in the elderly and the immunocompromised. Depending on patient age, mortality can reach up to $20 \%$ with the possibility of neurological sequelae $[95,96]$.

\subsubsection{SLEV}

Patients suffering from SLEV present with pleocytosis in the cerebrospinal fluid (CSF), in which PMN cells are the most abundant cell population. Clearance of viruses and leukocytes from CSF are indicative of resolution of infection and disease. Autopsy analyses of human brains show that flaviviral encephalitis results in brain tissue damage including neuronal death and is usually accompanied by aseptic meningitis [97].

Neutrophils are probably recruited early in the onset of SLEV, though by the time patients manifest severe symptoms and reach intensive care, leukocyte populations recruited to the brain are mostly composed of mononuclear leukocytes, primarily T lymphocytes [95]. Thus, neutrophils are known to participate in severe neurological disease caused by SLEV, but it is unknown whether neutrophils contribute to protection or disease development. In accordance with in-vivo studies with other flaviviruses, mouse models of SLEV infection have shown that viral replication and access to the central nervous system are major factors in disease development, as absence of a functional type-I IFN response renders mice completely susceptible to SLEV infection, disease and death [98]. Excessive SLEV replication in the tissues of IFNAR ${ }^{-/-}$mice result in early and aggravated onset of neurological disease, including the production of the neutrophil-chemoattractant CXCL1 and increases in MPO levels in infected brains $[95,98]$.

As mentioned previously, adult WT mice are resistant to flavivirus infection via peripheral inoculation routes. Using a mouse model of SLEV infection that employs direct inoculation of virus in the brain of immunocompetent adult mice, researchers were able to recapitulate most features of St. Louis encephalitis seen in human infection [95]. Besides SLEV replication in the CNS, brain damage and death, researchers reported the recruitment of neutrophils to infected brains using flow cytometry. Neutrophil recruitment directly correlated with disease development, and was preceded by the expression of proinflammatory cytokines and the chemokine CXCL1, suggesting that this chemokine and 
the CXCR2 receptor may play a role in neutrophil recruitment to SLEV-infected brains [95] (Figure 2).

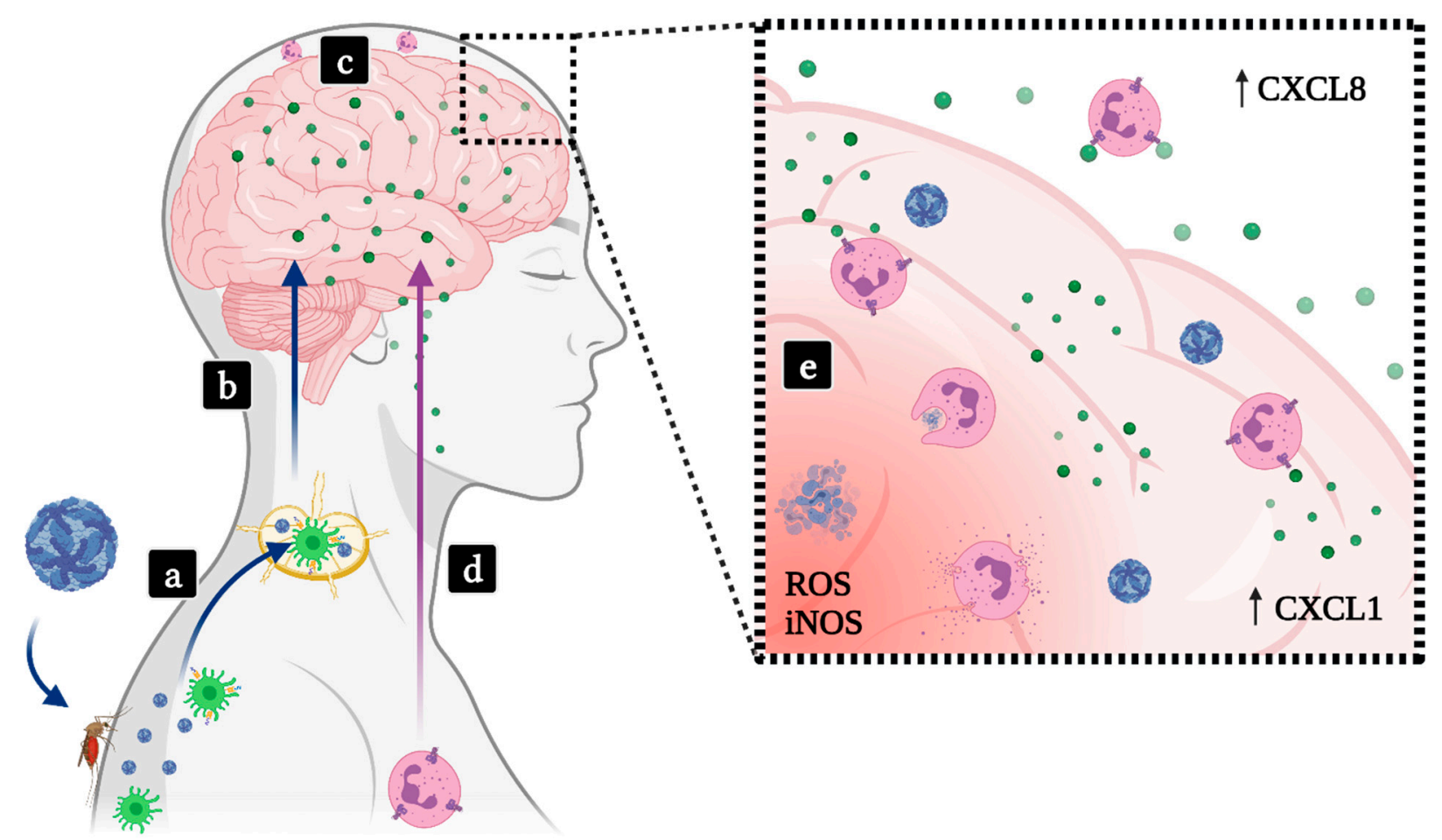

Figure 2. Involvement of neutrophils in flavivirus-induced encephalitis. (a) Encephalitic flavivirus such as WNV, JEV, SLEV, MVEV or TBEV (blue viral particles) are transmitted to vertebrate hosts through a mosquito or tick bite, reach resident mononuclear phagocytes in the skin and later disseminate to lymph nodes. (b) Neurotropic flaviviruses cross the blood-brain barrier through uncertain mechanisms, infecting cells in the CNS. (c) Infected neurons and activated glial cells release neutrophil-attracting chemokines in the CNS, initiating the development of encephalitis or meningoencephalitis. (d) Circulating neutrophils and other leukocytes are recruited to the CNS, resulting in CSF pleocytosis often observed in patients and consolidating the onset of severe disease. (e) High levels of CXC chemokines in the brain and CSF contribute to neutrophil activation and trigger neutrophil effector functions in situ, which may contribute to tissue damage, sequelae or death. Green dots-CXC chemokines.

\subsubsection{JEV}

The overall symptoms of Japanese encephalitis are similar to other encephalitic flaviviruses. Given the high degree of identity between encephalitic flaviviruses, antibody cross-protective immunity is observed. Brain damage and neuronal loss during JEV infections are associated with increased inflammation marked by increased levels of TNF- $\alpha$, IL-1 $\beta$, CCL5, CCL2 and NO $[99,100]$. JEV infection in humans and mice leads to cellular infiltration in the brain and spleen with major increases in neutrophil counts in the periphery and in the CSF. Serological examinations of patients infected with JEV have shown a worse disease outcome associated with a higher percentage of neutrophils and a lower percentage of lymphocytes [101,102].

The link between microglia and neutrophil influx to the brain is not clear. Singh et al. demonstrated how JEV-induced CCR2 expression regulates microglia activation and is associated with an increase in NO and proinflammatory cytokines TNF- $\alpha$ and IFN- $\gamma$ [103]. Moreover, patients with worse JEV encephalitis outcomes have increased and persistent levels of CXCL8 in the CSF, suggesting neutrophils are associated with worse disease outcomes [104]. Neutrophils were shown to play an important role in early antiviral defense against JEV by degrading phagocytosed JE virions. Conversely, JEVstimulated neutrophils release significant amounts of ROS, aggravating tissue damage 
and neurotoxicity [105]. More studies are needed to elucidate how neutrophils act as "double-edged swords" in JEV encephalitis.

\subsubsection{WNV}

Neutrophils accumulate in the CSF during WNV encephalitis. Neutrophilic meningitis is seen in approximately $50 \%$ of patients presenting with WNV neuroinvasive disease [106]. As stated, the role of neutrophils in disease development is not clear. The role of polymorphonuclear cells during in-vivo WNV infection was investigated and discussed by Bai and colleagues [107], who observed that macrophages quickly express high levels of Cxcl1 and Cxcl2 upon infection, leading to the recruitment of polymorphonuclear cells. Depletion of polymorphonuclear cells (PMN) after WNV infection led to increased viremia and early mortality. In contrast, PMN depletion prior to infection in CXCL2-deficient mice resulted in lower viremia and increased survival [107]. This data illustrate how neutrophils can have both protective and pathogenic roles in WNV encephalitis depending on timing of neutrophil depletion.

Experiments using human and mouse cells have shown that the proinflammatory chemokine osteopontin (OPN) is increased during WNV infections. OPN-deficient mice infected with WNV show similar levels of PMNs in blood and peripheral organs in comparison to infected wild-type mice. The lack of OPN leads to decreased PMN infiltration and WNV viral load in mice brains, suggesting that OPN expression facilitates the access of both PMN and WNV to the brain. Authors proposed a mechanism of neuroinvasion for WNV in which PMNs act like "Trojan Horses", although neutrophils are not considered target cells nor support flavivirus replication [108].

\subsection{4. $\mathrm{MVEV}$}

MVEV is a mosquito-borne flavivirus endemic to northern Australia. In-vivo studies using mouse models of infection have shown that peripheral inoculation of MVEV causes encephalitis in an age-dependent fashion [109]. As the elderly are a major risk group for encephalitic flavivirus, this MVEV mouse model is considered a useful model to study arbovirus-mediated encephalitis [110]. Neurotropism of MVEV in mice is evident and takes place 4 days after peripheral inoculation. On day 5 p.i., MVEV reaches the anterior olfactory nucleus, the piriform cortex and the hippocampus in the brain, following detection in the cerebral cortex, caudate putamen, thalamus and brain stem up to day 9 p.i. [110,111].

Matthews and colleagues used electron microscopy to show that lymphocytes, macrophages and especially neutrophils are recruited to infected, inflamed brains. Most leukocytes were apoptotic and shown to be abutted onto neurons [112]. Neutrophils have a major role in the development of MVEV encephalitis on day 5 p.i., and neutrophil infiltration to the CNS causes an increase in the levels of TNF- $\alpha$ and the neutrophil-attracting chemokine CXCL1 in the CNS. Moreover, increased levels of inducible nitric oxide synthase (iNOS) are also detected and correlates neutrophil infiltration and the onset of disease. Experiments involving the depletion of neutrophils and inhibition of iNOS led to prolonged or increased survival rates, suggesting a direct link between neutrophil recruitment to the brain, local expression of iNOS and the severity of MVEV encephalitis [110].

\subsubsection{TBEV}

TBEV is a flavivirus exclusively present in colder regions of Europe and Asia. TBEV is transmitted to humans mainly by Ixodes ricinus ticks [113]. Severe disease caused by TBEV manifest as encephalitis, similar to mosquito-borne encephalitic flavivirus, as indicated the virus name $[113,114]$. The study by Plekhova et al. showed the presence of TBEV in the cytoplasm of primary guinea pig neutrophils, using indirect fluorescence. Authors also observed that neutrophils had an increase in chromatin condensation and that several neutrophils were apoptotic. As previously mentioned, there is no robust data indicating that flavivirus can infect neutrophils in vivo [115]. Thangamani et al. have studied the transcriptional immune profile in early stages of TBEV infection. Experiments in mice 
suggest a neutrophil-dominated immune response early after blood meal, inferred by the increase in transcriptional levels of neutrophil-associated chemokines and cytokines. The study points out mononuclear phagocytes and fibroblasts as the primary target cells for TBEV in the skin using immunohistochemistry to detect viral proteins. Although neutrophils were markedly increased at the tick feeding site in the skin, authors did not observe the presence of TBEV antigens in neutrophils, suggesting that neutrophils play an important role in host immunomodulation after blood meal and virus transmission, but are not infected by TBEV [116].

\subsection{Implications in Pregnancy}

In "Experimental studies of congenital malformations", James G. Wilson compiled all known teratogenic agents at that time, defined as capable of causing abnormalities in embryonic or fetal development [117]. Teratogenic agents were classified into several groups: drugs and chemicals; physical agents (e.g., temperature); growth and metabolic inhibitors; maternal nutritional deficiencies; endocrine imbalances; and infections (known as TORCH agents nowadays). Later on, in 1977, Wilson defined the signs of abnormal development as death, malformation, growth retardation and functional disorder, which includes neurological dysfunction and effects on behavior and cognition that may manifest later in life [118]. The embryonic stage is the most sensitive period to teratogen action, including viral infection, and takes place from two to eight weeks post conception, a period when women may not be aware of pregnancy [119]. In fact, infections during pregnancy are considered to be one of the major causes of maternal, fetal and neonatal mortality and morbidity [120]. Following the events of the ZIKV epidemics in 2015, this flavivirus has been classified as a teratogen among TORCH agents. ZIKV infection led to thousands of Congenital Zika Syndrome (CZS) cases, mostly in Brazil [121]. The literature reports that not only ZIKV, but also JEV, WNV and SLEV infections during pregnancy may lead to intrauterine-growth restriction (IUGR), congenital malformations and/or fetal demise, the ultimate manifestations of the action of teratogenic agents [118].

During pregnancy, the maternal organism undergoes several adaptations to tolerate the presence of the fetus and also support its development until parturition. Those are immunological, physiological and hormonal adaptations taking place at the placenta and maternal-fetal interface [122,123], but also systemically [124]. Evidence suggests an increased susceptibility of pregnant women to viral infections due to aforementioned changes in the maternal immunological profile [125], notably a shift in towards a predominantly humoral immune response rather than cytotoxic [126]. Conversely, the number of circulatory PMN cells increases progressively throughout gestation, in association to increasing G-CSF plasma levels and peaking in the third trimester. During labor, neutrophil density is selectively greater in the lower uterine segment, presenting a rich source of inflammatory mediators such as eicosanoids, collagenase, elastase, IL-1 $\beta$ and TNF- $\alpha$ [127-129]. Baseline neutrophil activation changes during pregnancy, characterized by increased expression of $\mathrm{CD} 11 \mathrm{~b}$ and higher responsiveness to stimuli, such as increased phagocytosis, degranulation, NETs release and higher production of ROS [130,131].

In the female reproductive tract, PMN cells dispose of invading pathogens by phagocytosis or degranulation [132]. However, their presence and activity are tightly regulated by steroidal hormone action on the epithelial cells from the female reproductive tract. The activation of estrogen receptor ESR1 in these cells downregulates epithelial factors required to initiate transepithelial migration, impairing the recruitment of neutrophils to vaginal tissues, but ensuring their integrity during pregnancy [133]. This regulatory network prevents undesirable immune activation, which often lead to gestational disorders such as pre-eclampsia, placental insufficiency and fetal growth restriction [134]. However, recurrent infections may disrupt this balance, enhancing placental constitutive expression of the neutrophil-chemoattractant CXCL8 [135], and leading to the accumulation of invading fetal and maternal neutrophils in amniotic fluid [136]. In fact, high levels of chemokines CXCL10 and CXCL8 were found in the sera of preeclamptic mothers [137], where CXCL8 
activates circulatory neutrophils and induces the release of NETs in the intervillous space of preeclamptic placenta [138]. Moreover, neutrophil abnormal activity is associated with severe pregnancy disturbances such as recurrent fetal loss, gestational diabetes mellitus, IUGR and preeclampsia [138,139].

Although flaviviruses have been identified as human viral pathogens for more than a century [140], the impacts of flavivirus infection on pregnancy outcomes are not well understood. Except for ZIKV, the literature of flaviviral infection during pregnancy is limited, often resumed on reports of transplacental infection. The mechanisms by which infection occurs and how it affects embryo or fetus development remain to be explored. For instance, DENV infection during pregnancy has been associated with increased risk of hemorrhagic fever and shock [141]. DENV infection in early pregnancy was associated with fetal loss and probable transplacental transmission [142,143], while perinatal infection may result in neonatal infection [144,145]. Two reports describe YFV congenital infection: the first, dating from 1940, described two cases of fatal maternal infection mid-gestation, in which autopsy of one patient showed retro-placental hemorrhage, generalized steatosis in the fetus, extensive bleeding and leukocyte infiltration in fetal liver, lesions in the hepatic gland and hemorrhages in the intestinal tract [146]; the second documented case describes the onset of yellow fever symptoms on a female patient three days before delivery, resulting in newborn fatal infection, in Brazil [147].

Regarding encephalitogenic flaviviruses, the natural and experimental JEV infection in swine led to fetus mummification and stillbirths [148,149]. The human transplacental infection with JEV was described for the first time in 1980, during an outbreak of Japanese encephalitis. The effects of JEV infection during pregnancy varied from parturition of apparently normal children to abortion, furthermore, it was possible to isolate JEV from brain, liver and placental tissues from an aborted fetus [150]. A mouse model of intrauterine infection with SLEV showed severe neurological outcomes in fetuses, and the severity of the disease depended on the gestational day of infection [151]. There is no data on maternal or fetal risks associated with SLEV congenital infection in humans [152]. In 2002, the CDC published the first case report on intrauterine WNV infection, the 2-day old infant presented positive serology for WNV, chorioretinal scarring and severe brain abnormalities $[153,154]$. An anomaly rate of $10.6 \%$ was reported in a clinical study of pregnant women infected with WNV in the USA, which is almost twice the rate of $5.5 \%$ for the general population and included four cases of miscarriage and four preterm deliveries. Of 55 infants born at term, most did not present anti-WNV IgM in cord serum, but some individuals developed a degree of malformation such as abnormal growth, aortic coarctation, glycogen storage disease type 1, cleft palate, Down syndrome, microcephaly, polydactyly or lissencephaly [155]. Moreover, WNV and Powassan virus (POWV, a tick-borne flavivirus) are capable of infecting and damaging human placental explants or pregnant mice placentas [156]. Whether these outcomes are caused by flaviviral infection per se or by dysregulation of immune response remains to be explored, along with possible molecular mechanisms involved.

The ZIKV epidemic in 2015 brought a significant increase in cases of microcephaly and congenital malformations in Brazil, and prompted the establishment of in-vitro and in-vivo models of infection to better understand ZIKV biology and pathogenesis [157]. Zika was shown to be a neurotropic flavivirus, capable of infecting not only neuronal cells but also trophoblasts in placenta and the developing embryo, which ultimately causes the Congenital Zika Syndrome (CZS). The most common clinical manifestations of CZS include microcephaly, ventriculomegaly, intracranial calcification, ocular abnormalities and hearing loss [158-160]. Pregnant women with symptomatic ZIKV infection showed higher viral load in sera than nonpregnant women [161]. In addition to other proinflammatory chemokines, Camacho-Zavala and colleagues found high plasma levels of CXCL8, which correlate directly to neutrophil activation [161] (Figure 3). Moreover, the amniotic fluid from ZIKV-positive pregnant women whose children presented microcephaly revealed exceedingly high levels of cytokines and growth factors: IL-15, CCL11, CXCL10, G-CSF, IL-10, IL-1 $\beta$, TNF- $\alpha$, CXCL8, CCL2 and CCL5 [162]. These data corroborate the proinflammatory 
profile found in pregnant Zika patients and are suggestive of neutrophil involvement, as G-CSF, CXCL8, IL-1 $\beta$ and TNF- $\alpha$ are involved in neutrophil activation and effector functions. Finally, cerebrospinal fluid from infants with ZIKV-induced microcephaly showed a maintenance of the inflammatory environment by the presence of IFN- $\alpha$, CXCL10 and CXCL9 after birth [163].

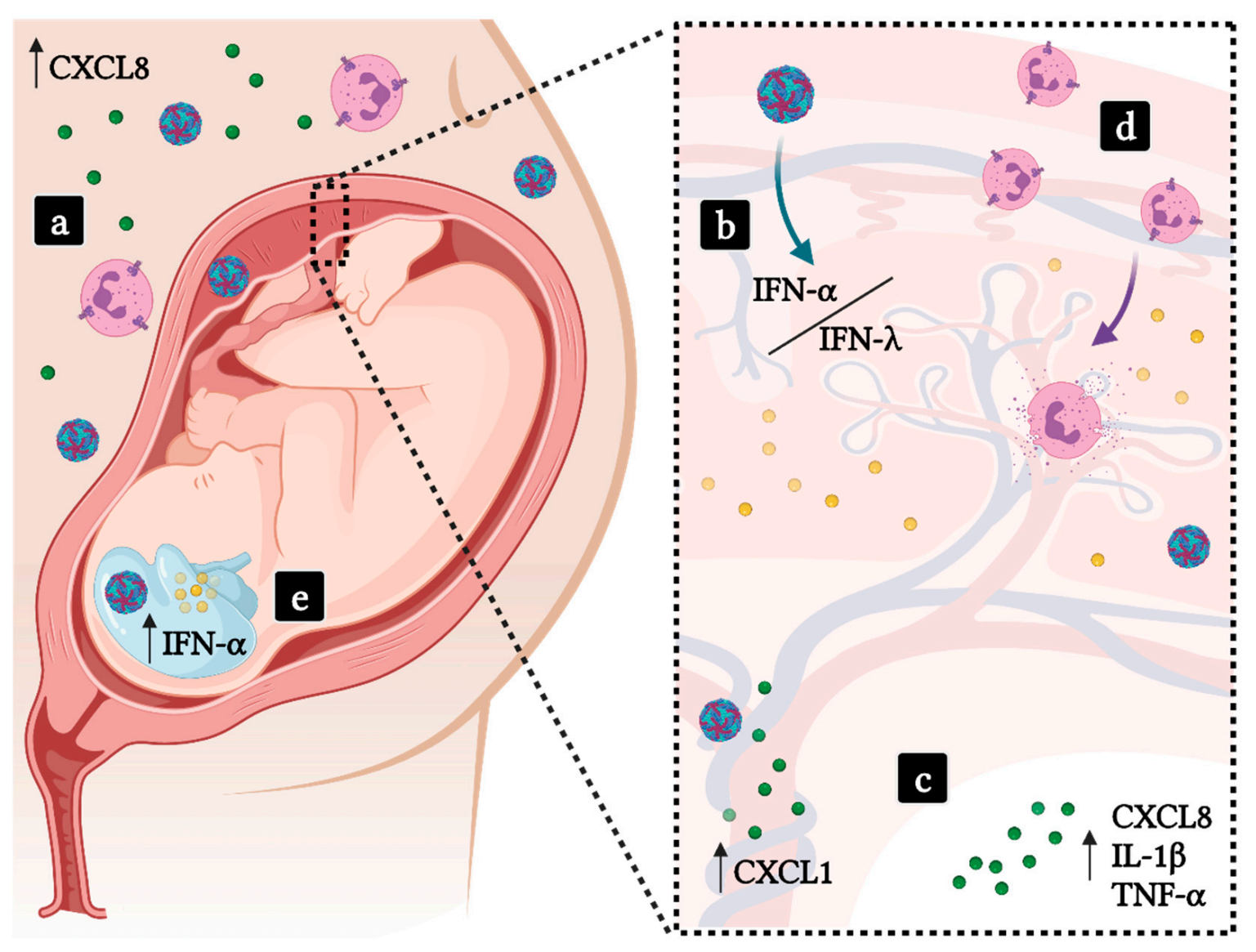

Figure 3. ZIKV congenital infection and the probable participation of neutrophils in CZS. (a) High levels of CXCL8 are found in the serum of pregnant women infected with ZIKV (blue/red viral particles). (b) ZIKV is able to trespass the placental barrier, the persistence of the infection leads to an imbalance on Type-I and Type-III IFN responses, which may lead to tissue damage. (c) Amniotic fluid from CZS pregnancies present high levels of neutrophil-chemoattractants and proinflammatory cytokines and ZIKV-infected human umbilical vein endothelial cells are sources of CXCL1. (d) Recruited neutrophils respond to pathogenic activation of Type-I IFN responses in patients. (e) ZIKV may infect fetal tissues, inducing a proinflammatory environment that promotes neuronal damage and the onset of CZS. Green dots-CXC chemokines; Yellow dots-IFNs.

Transcriptome profile of human umbilical vein endothelial cells (HUVEC) infected in vitro with ZIKV revealed upregulation of IL-15, CCL5, HGF, LIF, M-CSF, CXCL1 and CXCL12 $24 \mathrm{~h}$ post infection. Cells infected with the Puerto Rican strain, a representative of Asian ZIKV strains, showed increased levels of IL-1 $\beta$, IL-10, CCL5, G-CSF, CSF, CXCL1 and CXCL12 cytokines and reduction of IL-15, IL-16, HGH, PDGFbb and CXCL9 cytokines. Inoculation of the African strain in HUVEC cell cultures resulted in a higher expression of CCL2, CCL5, bFGF, G-CSF, LIF, M-CSF, CXCL1, and CXCL12 and a decrease in IL15, HGH and CXCL11 [164]. Recurrent expression of CXCL1 and CXCL12 suggests that ZIKV infection of umbilical endothelial cells may lead to neutrophil recruitment to the umbilical cord.

Placentas infected with ZIKV develop a type-III IFN response in the decidua. Usually, IFN- $\lambda$ has been shown to be protective against infections in mucosal surfaces, inducing 
antiviral responses with minimal damage to tissues. In the context of the placenta, IFN- $\lambda$ is also tissue-protective, sustaining the placental role as a barrier and by counteracting infection through induction of ISGs. Human trophoblast cells isolated from full-term placentas were refractory to ZIKV infection due to IFN- $\lambda 1$ expression [165]. Neutrophils express high levels of the heterodimeric IFN- $\lambda$ receptor IFNLR1/IL10RB [166], resulting in a repressed state of neutrophils' effector functions induced by type-III IFN signaling, exemplified by reduction in neutrophil infiltration, degranulation, ROS production and NETs release [167]. In the early stages of ZIKV placental infection, typical flavivirus antagonism of IFN responses result in downregulation of IFN- $\lambda 2$, leading to an aberrant neutrophil response and CZS [168]. CZS is later accompanied by a strong type-I IFN response, increased expression of IFIT5 and decrease of ISG15 mRNA expression levels [169]. Studies using mouse models of ZIKV infection show that fetal and placental type-I IFN responses play a major role in promoting placental damage and fetal demise in ZIKV congenital infection [169,170]. The activation of a robust type-I IFN response may lead to tissue damage through induction of chemokine expression and recruitment of neutrophils, proinflammatory monocytes and T lymphocytes [171]. High levels of IFN- $\alpha$ early in pregnancy may cause angiogenic imbalance in the placenta, associated with higher risks for preeclampsia [172]. Hence, the proinflammatory environment promoted by ZIKV infection during pregnancy indicates that neutrophils may be recruited to infected tissues and that neutrophil functions may be dysregulated.

\section{Final Considerations}

Significant advances have been made towards a better understanding of severe forms of flavivirus-induced disease, notably on the identification of target cells for viral replication, characterization of proinflammatory mediators produced during infection and the roles of antiviral IFN responses in restricting viral replication and disease. Patients suffering from flaviviral diseases are given supportive care, as all flaviviral diseases still lack specific treatment. A lack of therapeutic options in flaviviral diseases are partially due to our incomplete understanding of severe disease pathogenesis, regardless of whether a mild disease evolves to encephalitis, hemorrhagic fever or congenital alterations.

Literature collected in this manuscript indicates that chemokines recruit neutrophils to sites of inflammation, where they participate in the immune response against flaviviruses and may, in some cases, contribute to immunopathogenesis and disease aggravation, as summarized in Table 1. Complex neutrophil responses take place as effector mechanisms such as NETs likely contribute to virus restriction, but chemokine-dependent neutrophil recruitment to target organs and the release of proinflammatory mediators, e.g., in the placenta or the CNS, are associated with tissue damage and disease development. In contrast to abundant studies on the role of neutrophils in bacterial infections or viral infections of the respiratory tract (e.g., Coronaviruses, Influenza viruses), the study of neutrophils in flavivirus infections is neglected. New studies focused on reverting such a limitation are likely to result in the discovery of new molecular mechanisms, and inspire the design of therapeutic strategies against disease and facilitate the development of candidate treatments. 
Table 1. Chemokines and cytokines associated with neutrophil functions in infection and severe diseases caused by flaviviruses. For each flavivirus addressed in this review (column "Virus"), a list of chemokines and cytokines is provided in the respective column and accompanied by a brief description on how these mediators affect neutrophil function and flaviviral severe disease development (column "Involvement"). DENV—Dengue virus, YFV-Yellow Fever virus, SLEV—St. Louis Encephalitis virus, JEV-Japanese Encephalitis virus, WNV-West Nile virus, MVEV-Murray Valley Encephalitis virus, TBEV—Tick-borne Encephalitis virus, ZIKV—Zika virus.

\begin{tabular}{|c|c|c|}
\hline Virus & Chemokines/Cytokines & Involvement \\
\hline $\begin{array}{l}\text { Flaviviruses transmitted through } \\
\text { Aedes mosquito bite }\end{array}$ & $\begin{array}{c}\text { CXCL1, CXCL2, CXCL3, CXCL5, } \\
\text { IL-1 } \beta, \text { IL-6 }\end{array}$ & $\begin{array}{l}\text { Promote local inflammation and recruitment of } \\
\text { target cells to the skin. }\end{array}$ \\
\hline DENV, YFV & $\begin{array}{c}\text { CXCL2, CXCL8, IL-6, TNF- } \alpha \\
\text { CCL2, IL-1 } \beta\end{array}$ & $\begin{array}{l}\text { Promote neutrophil activation in dengue. } \\
\text { High expression was associated with increased } \\
\text { disease severity in yellow fever. }\end{array}$ \\
\hline SLEV & CXCL1 & Neutrophil recruitment to infected brain tissue. \\
\hline JEV & $\begin{array}{l}\text { CCL2, CCL5, TNF- } \alpha, \text { IL-1 } \beta \\
\text { CXCL8 }\end{array}$ & $\begin{array}{l}\text { High levels were associated to brain damage and } \\
\text { neuronal loss. } \\
\text { Accumulation in CSF in severe cases. }\end{array}$ \\
\hline WNV & $\begin{array}{l}\text { CXCL1, CXCL2 } \\
\text { OPN }\end{array}$ & $\begin{array}{l}\text { Involved in PMN recruitment to infected tissues. } \\
\text { Facilitates infiltration of virus and PMNs } \\
\text { in the brain. }\end{array}$ \\
\hline MVEV & CXCL1, TNF- $\alpha$ & $\begin{array}{l}\text { Neutrophil recruitment and activation, also } \\
\text { related to increased disease severity. }\end{array}$ \\
\hline TBEV & $\begin{array}{c}\text { CCL2, CCL12, CXCL1, CXCL2, CXCL5, } \\
\text { IL-6, IL-10 }\end{array}$ & $\begin{array}{l}\text { Upregulated in cutaneous tissue during early } \\
\text { stages of infection. }\end{array}$ \\
\hline ZIKV & $\begin{array}{l}\text { CCL11, CXCL10, CXCL8, CCL2, CCL5, } \\
\text { G-CSF, IL-1 } \beta, \text { TNF- } \alpha \\
\text { CXCL10, CXCL9, IFN- } \alpha \\
\text { CXCL1, CXCL12 }\end{array}$ & $\begin{array}{l}\text { High levels in the amniotic fluid from infected } \\
\text { mothers whose children presented microcephaly. } \\
\text { Associated with persistent inflammation in the } \\
\text { CSF of infants with microcephaly. } \\
\text { Probably associated with neutrophil recruitment } \\
\text { to umbilical cord during ZIKV infection. } \\
\text { Protective effect against ZIKV placental infection, } \\
\text { also downregulates neutrophils } \\
\text { effector functions. } \\
\text { Generally protective against virus infections. } \\
\text { However, may lead to aberrant neutrophilic } \\
\text { response in CZS and placental damage. }\end{array}$ \\
\hline
\end{tabular}

Author Contributions: Conceptualization, M.A.F., R.F.R. and R.E.M.; writing-original draft preparation, M.A.F. and R.F.R.; writing - review and editing, R.E.M.; visualization, R.E.M.; supervision, R.E.M. All authors have read and agreed to the published version of the manuscript.

Funding: M.A.F. is supported by a CNPq scholarship (141253/2019-3). R.F.R. is supported by FAPESP scholarships (2018/02594-9; 2019/20772-4). R.E.M. is the recipient of a FAPESP FWO bilateral grant (18/10990-1).

Institutional Review Board Statement: Not applicable.

Informed Consent Statement: Not applicable.

Data Availability Statement: No new data were created or analyzed in this study. Data sharing is not applicable to this article.

Acknowledgments: Figures were created with BioRender (www.biorender.com, accessed on 20 June 2021).

Conflicts of Interest: The authors declare no conflict of interest. The funders had no role in the design of the study; in the collection, analyses, or interpretation of data; in the writing of the manuscript, or in the decision to publish the results. 


\section{References}

1. Marques, R.E.; Guabiraba, R.; Cisalpino, D.; Teixeira, M.M.; Souza, D.G. Dengue. Colloquium Series on Integrated Systems Physiology: From Molecule to Function; Morgan \& Claypool Life Sciences: San Rafael, CA, USA, 2014; Volume 6, pp. 1-104. [CrossRef]

2. Rothman, A.L. Immunity to Dengue Virus: A Tale of Original Antigenic Sin and Tropical Cytokine Storms. Nat. Rev. Immunol. 2011, 11, 532-543. [CrossRef] [PubMed]

3. Rosa, R.; Costa, E.A.; Marques, R.E.; Oliveira, T.S.; Furtini, R.; Bomfim, M.R.Q.; Teixeira, M.M.; Paixão, T.A.; Santos, R.L. Isolation of Saint Louis Encephalitis Virus from a Horse with Neurological Disease in Brazil. PLoS Negl. Trop. Dis. 2013, 7, e2537. [CrossRef]

4. $\quad$ Ribeiro, L.S.; Marques, R.E.; de Jesus, A.M.R.; de Almeida, R.P.; Teixeira, M.M. Zika Crisis in Brazil: Challenges in Research and Development. Curr. Opin. Virol. 2016, 18, 76-81. [CrossRef]

5. Zuchi, N.; da Silva Heinen, L.B.; dos Santos, M.A.M.; Pereira, F.C.; Slhessarenko, R.D. Molecular Detection of Mayaro Virus during a Dengue Outbreak in the State of Mato Grosso, Central-West Brazil. Mem. Inst. Oswaldo Cruz 2014, 109, 820-823. [CrossRef] [PubMed]

6. Tamba, M.; Bonilauri, P.; Bellini, R.; Calzolari, M.; Albieri, A.; Sambri, V.; Dottori, M.; Angelini, P. Detection of Usutu Virus within a West Nile Virus Surveillance Program in Northern Italy. Vector Borne Zoonotic Dis. 2011, 11, 551-557. [CrossRef] [PubMed]

7. Pierson, T.C.; Diamond, M.S. The Continued Threat of Emerging Flaviviruses. Nat. Microbiol. 2020, 5, 796-812. [CrossRef]

8. Rocha, R.F.; Del Sarto, J.L.; Marques, R.E.; Costa, V.V.; Teixeira, M.M. Host Target-Based Approaches against Arboviral Diseases. Biol. Chem. 2018, 399, 203-217. [CrossRef]

9. Kantari, C.; Pederzoli-Ribeil, M.; Witko-Sarsat, V. The Role of Neutrophils and Monocytes in Innate Immunity. Contrib. Microbiol. 2008, 15, 118-146. [CrossRef]

10. Németh, T.; Sperandio, M.; Mócsai, A. Neutrophils as Emerging Therapeutic Targets. Nat. Rev. Drug Discov. 2020, 19, 253-275. [CrossRef]

11. Németh, T.; Mócsai, A. Feedback Amplification of Neutrophil Function. Trends Immunol. 2016, 37, 412-424. [CrossRef]

12. Lämmermann, T.; Afonso, P.V.; Angermann, B.R.; Wang, J.M.; Kastenmüller, W.; Parent, C.A.; Germain, R.N. Neutrophil Swarms Require LTB4 and Integrins at Sites of Cell Death In Vivo. Nature 2013, 498, 371-375. [CrossRef]

13. McDonald, B.; Kubes, P. Cellular and Molecular Choreography of Neutrophil Recruitment to Sites of Sterile Inflammation. J. Mol. Med. 2011, 89, 1079-1088. [CrossRef]

14. Futosi, K.; Fodor, S.; Mócsai, A. Reprint of Neutrophil Cell Surface Receptors and Their Intracellular Signal Transduction Pathways. Int. Immunopharmacol. 2013, 17, 1185-1197. [CrossRef] [PubMed]

15. Petri, B.; Sanz, M.-J. Neutrophil Chemotaxis. Cell Tissue Res. 2018, 371, 425-436. [CrossRef] [PubMed]

16. Zlotnik, A.; Yoshie, O. The Chemokine Superfamily Revisited. Immunity 2012, 36, 705-716. [CrossRef]

17. Plagge, M.; Laskay, T. Early Production of the Neutrophil-Derived Lipid Mediators LTB4 and LXA4 Is Modulated by Intracellular Infection with Leishmania major. BioMed Res. Int. 2017, 2017, 2014583. [CrossRef] [PubMed]

18. Tecchio, C.; Micheletti, A.; Cassatella, M.A. Neutrophil-Derived Cytokines: Facts beyond Expression. Front. Immunol. 2014, 5, 508. [CrossRef]

19. Michalec, L.; Choudhury, B.K.; Postlethwait, E.; Wild, J.S.; Alam, R.; Lett-Brown, M.; Sur, S. CCL7 and CXCL10 Orchestrate Oxidative Stress-Induced Neutrophilic Lung Inflammation. J. Immunol. 2002, 168, 846-852. [CrossRef]

20. Dupré-Crochet, S.; Erard, M.; Nüße, O. ROS Production in Phagocytes: Why, When, and Where? J. Leukoc. Biol. 2013, 94, 657-670. [CrossRef]

21. Cowland, J.B.; Borregaard, N. Granulopoiesis and Granules of Human Neutrophils. Immunol. Rev. 2016, 273, 11-28. [CrossRef]

22. Parmley, R.T.; Rice, W.G.; Kinkade, J.M., Jr.; Gilbert, C.; Barton, J.C. Peroxidase-Containing Microgranules in Human Neutrophils: Physical, Morphological, Cytochemical, and Secretory Properties. Blood 1987, 70, 1630-1638. [CrossRef]

23. Rice, W.G.; Kinkade, J.M., Jr.; Parmley, R.T. High Resolution of Heterogeneity among Human Neutrophil Granules: Physical, Biochemical, and Ultrastructural Properties of Isolated Fractions. Blood 1986, 68, 541-555. [CrossRef]

24. Wong, S.H.; Francis, N.; Chahal, H.; Raza, K.; Salmon, M.; Scheel-Toellner, D.; Lord, J.M. Lactoferrin Is a Survival Factor for Neutrophils in Rheumatoid Synovial Fluid. Rheumatology 2009, 48, 39-44. [CrossRef]

25. Oseas, R.; Yang, H.H.; Baehner, R.L.; Boxer, L.A. Lactoferrin: A Promoter of Polymorphonuclear Leukocyte Adhesiveness. Blood 1981, 57, 939-945. [CrossRef]

26. Delclaux, C.; Delacourt, C.; D’Ortho, M.P.; Boyer, V.; Lafuma, C.; Harf, A. Role of Gelatinase B and Elastase in Human Polymorphonuclear Neutrophil Migration across Basement Membrane. Am. J. Respir. Cell Mol. Biol. 1996, 14, $288-295$. [CrossRef] [PubMed]

27. Miller, L.J.; Bainton, D.F.; Borregaard, N.; Springer, T.A. Stimulated Mobilization of Monocyte Mac-1 and p150,95 Adhesion Proteins from an Intracellular Vesicular Compartment to the Cell Surface. J. Clin. Investig. 1987, 80, 535-544. [CrossRef]

28. Brinkmann, V.; Reichard, U.; Goosmann, C.; Fauler, B.; Uhlemann, Y.; Weiss, D.S.; Weinrauch, Y.; Zychlinsky, A. Neutrophil Extracellular Traps Kill Bacteria. Science 2004, 303, 1532-1535. [CrossRef] [PubMed]

29. Czaikoski, P.G.; Mota, J.M.S.C.; Nascimento, D.C.; Sônego, F.; Varas e Silva Castanheira, F.; Melo, P.H.; Scortegagna, G.T.; Silva, R.L.; Barroso-Sousa, R.; Souto, F.O.; et al. Neutrophil Extracellular Traps Induce Organ Damage during Experimental and Clinical Sepsis. PLoS ONE 2016, 11, e0148142. [CrossRef]

30. Colón, D.F.; Wanderley, C.W.; Franchin, M.; Silva, C.M.; Hiroki, C.H.; Castanheira, F.V.S.; Donate, P.B.; Lopes, A.H.; Volpon, L.C.; Kavaguti, S.K.; et al. Neutrophil Extracellular Traps (NETs) Exacerbate Severity of Infant Sepsis. Crit. Care 2019, 23, 113. [CrossRef] 
31. Agraz-Cibrian, J.M.; Giraldo, D.M.; Mary, F.-M.; Urcuqui-Inchima, S. Understanding the Molecular Mechanisms of NETs and Their Role in Antiviral Innate Immunity. Virus Res. 2017, 228, 124-133. [CrossRef] [PubMed]

32. Cortjens, B.; de Boer, O.J.; de Jong, R.; Antonis, A.F.; Sabogal-Piñeros, Y.S.; Lutter, R.; van Woensel, J.B.; Bem, R.A. Neutrophil Extracellular Traps Cause Airway Obstruction during Respiratory Syncytial Virus Disease. J. Pathol. 2016, $238,401-411$. [CrossRef] [PubMed]

33. Muraro, S.P.; De Souza, G.F.; Gallo, S.W.; Da Silva, B.K.; De Oliveira, S.D.; Vinolo, M.A.R.; Saraiva, E.M.; Porto, B.N. Respiratory Syncytial Virus Induces the Classical ROS-Dependent NETosis through PAD-4 and Necroptosis Pathways Activation. Sci. Rep. 2018, 8, 14166. [CrossRef]

34. Hiroki, C.H.; Toller-Kawahisa, J.E.; Fumagalli, M.J.; Colon, D.F.; Figueiredo, L.T.M.; Fonseca, B.A.L.D.; Franca, R.F.O.; Cunha, F.Q. Neutrophil Extracellular Traps Effectively Control Acute Chikungunya Virus Infection. Front. Immunol. 2019, $10,3108$. [CrossRef] [PubMed]

35. Buckley, C.D.; Gilroy, D.W.; Serhan, C.N. Proresolving Lipid Mediators and Mechanisms in the Resolution of Acute Inflammation. Immunity 2014, 40, 315-327. [CrossRef]

36. Stark, M.A.; Huo, Y.; Burcin, T.L.; Morris, M.A.; Olson, T.S.; Ley, K. Phagocytosis of Apoptotic Neutrophils Regulates Granulopoiesis via IL-23 and IL-17. Immunity 2005, 22, 285-294. [CrossRef]

37. Pérez-Figueroa, E.; Álvarez-Carrasco, P.; Ortega, E.; Maldonado-Bernal, C. Neutrophils: Many Ways to Die. Front. Immunol. 2021, 12, 631821. [CrossRef]

38. Mogensen, T.H. Pathogen Recognition and Inflammatory Signaling in Innate Immune Defenses. Clin. Microbiol. Rev. 2009, 22, 240-273. [CrossRef]

39. Kawai, T.; Akira, S. Innate Immune Recognition of Viral Infection. Nat. Immunol. 2006, 7, 131-137. [CrossRef]

40. Taylor, K.E.; Mossman, K.L. Recent Advances in Understanding Viral Evasion of Type I Interferon. Immunology 2013, 138, 190-197. [CrossRef] [PubMed]

41. Muralidharan, A.; Reid, S.P. Complex Roles of Neutrophils during Arboviral Infections. Cells 2021, 10, 1324. [CrossRef] [PubMed]

42. Broggi, A.; Tan, Y.; Granucci, F.; Zanoni, I. IFN- $\lambda$ Suppresses Intestinal Inflammation by Non-Translational Regulation of Neutrophil Function. Nat. Immunol. 2017, 18, 1084-1093. [CrossRef]

43. Metzemaekers, M.; Cambier, S.; Blanter, M.; Vandooren, J.; de Carvalho, A.C.; Malengier-Devlies, B.; Vanderbeke, L.; Jacobs, C.; Coenen, S.; Martens, E.; et al. Kinetics of Peripheral Blood Neutrophils in Severe Coronavirus Disease 2019. Clin. Transl. Immunol. 2021, 10, e1271. [CrossRef] [PubMed]

44. Crovatto, M.; Pozzato, G.; Zorat, F.; Pussini, E.; Nascimben, F.; Baracetti, S.; Grando, M.G.; Mazzaro, C.; Reitano, M.; Modolo, M.L.; et al. Peripheral Blood Neutrophils from Hepatitis C Virus-Infected Patients Are Replication Sites of the Virus. Haematologica 2000, 85, 356-361.

45. Tate, M.D.; Ioannidis, L.J.; Croker, B.; Brown, L.E.; Brooks, A.G.; Reading, P.C. The Role of Neutrophils during Mild and Severe Influenza Virus Infections of Mice. PLoS ONE 2011, 6, e17618. [CrossRef] [PubMed]

46. Levitt, N.H.; Miller, H.V.; Edelman, R. Interaction of Alphaviruses with Human Peripheral Leukocytes: In Vitro Replication of Venezuelan Equine Encephalomyelitis Virus in Monocyte Cultures. Infect. Immun. 1979, 24, 642-646. [CrossRef] [PubMed]

47. Abramson, J.S.; Wheeler, J.G.; Parce, J.W.; Rowe, M.J.; Lyles, D.S.; Seeds, M.; Bass, D.A. Suppression of Endocytosis in Neutrophils by Influenza A Virus In Vitro. J. Infect. Dis. 1986, 154, 456-463. [CrossRef] [PubMed]

48. Zhao, Y.; Lu, M.; Lau, L.T.; Lu, J.; Gao, Z.; Liu, J.; Yu, A.C.H.; Cao, Q.; Ye, J.; McNutt, M.A.; et al. Neutrophils May Be a Vehicle for Viral Replication and Dissemination in Human H5N1 Avian Influenza. Clin. Infect. Dis. 2008, 47, 1575-1578. [CrossRef]

49. Halfhide, C.P.; Flanagan, B.F.; Brearey, S.P.; Hunt, J.A.; Fonceca, A.M.; McNamara, P.S.; Howarth, D.; Edwards, S.; Smyth, R.L. Respiratory Syncytial Virus Binds and Undergoes Transcription in Neutrophils from the Blood and Airways of Infants with Severe Bronchiolitis. J. Infect. Dis. 2011, 204, 451-458. [CrossRef]

50. Mohamadzadeh, M.; Coberley, S.S.; Olinger, G.G.; Kalina, W.V.; Ruthel, G.; Fuller, C.L.; Swenson, D.L.; Pratt, W.D.; Kuhns, D.B.; Schmaljohn, A.L. Activation of Triggering Receptor Expressed on Myeloid Cells-1 on Human Neutrophils by Marburg and Ebola Viruses. J. Virol. 2006, 80, 7235-7244. [CrossRef]

51. Larochelle, B.; Flamand, L.; Gourde, P.; Beauchamp, D.; Gosselin, J. Epstein-Barr Virus Infects and Induces Apoptosis in Human Neutrophils. Blood 1998, 92, 291-299. [CrossRef]

52. Hartshorn, K.L.; Liou, L.S.; White, M.R.; Kazhdan, M.M.; Tauber, J.L.; Tauber, A.I. Neutrophil Deactivation by Influenza A Virus. Role of Hemagglutinin Binding to Specific Sialic Acid-Bearing Cellular Proteins. J. Immunol. 1995, 154, 3952-3960. [PubMed]

53. Daigneault, D.E.; Hartshorn, K.L.; Liou, L.S.; Abbruzzi, G.M.; White, M.R.; Oh, S.K.; Tauber, A.I. Influenza A Virus Binding to Human Neutrophils and Cross-Linking Requirements for Activation. Blood 1992, 80, 3227-3234. [CrossRef]

54. Grudzinska, F.S.; Sapey, E. Friend or Foe? The Dual Role of Neutrophils in Lung Injury and Repair. Thorax 2018, 73, 305-307. [CrossRef] [PubMed]

55. Butterfield, T.A.; Best, T.M.; Merrick, M.A. The Dual Roles of Neutrophils and Macrophages in Inflammation: A Critical Balance between Tissue Damage and Repair. J. Athl. Train. 2006, 41, 457-465.

56. Johansson, C.; Kirsebom, F.C.M. Neutrophils in Respiratory Viral Infections. Mucosal Immunol. 2021. [CrossRef]

57. Hayden, F.G.; Fritz, R.; Lobo, M.C.; Alvord, W.; Strober, W.; Straus, S.E. Local and Systemic Cytokine Responses during Experimental Human Influenza A Virus Infection. Relation to Symptom Formation and Host Defense. J. Clin. Investig. 1998, 101, 643-649. [CrossRef] 
58. Lee, N.; Wong, C.K.; Chan, P.K.S.; Chan, M.C.W.; Wong, R.Y.K.; Lun, S.W.M.; Ngai, K.L.K.; Lui, G.C.Y.; Wong, B.C.K.; Lee, S.K.W.; et al. Cytokine Response Patterns in Severe Pandemic 2009 H1N1 and Seasonal Influenza among Hospitalized Adults. PLoS ONE 2011, 6, e26050. [CrossRef] [PubMed]

59. Fritz, R.S.; Hayden, F.G.; Calfee, D.P.; Cass, L.M.; Peng, A.W.; Alvord, W.G.; Strober, W.; Straus, S.E. Nasal Cytokine and Chemokine Responses in Experimental Influenza A Virus Infection: Results of a Placebo-Controlled Trial of Intravenous Zanamivir Treatment. J. Infect. Dis. 1999, 180, 586-593. [CrossRef]

60. Bjornson, A.B.; Mellencamp, M.A.; Schiff, G.M. Complement Is Activated in the Upper Respiratory Tract during Influenza Virus Infection. Am. Rev. Respir. Dis. 1991, 143, 1062-1066. [CrossRef]

61. Garcia, C.C.; Weston-Davies, W.; Russo, R.C.; Tavares, L.P.; Rachid, M.A.; Alves-Filho, J.C.; Machado, A.V.; Ryffel, B.; Nunn, M.A.; Teixeira, M.M. Complement C5 Activation during Influenza a Infection in Mice Contributes to Neutrophil Recruitment and Lung Injury. PLOS ONE 2013, 8, e64443. [CrossRef]

62. Schmitz, N.; Kurrer, M.; Bachmann, M.F.; Kopf, M. Interleukin-1 Is Responsible for Acute Lung Immunopathology but Increases Survival of Respiratory Influenza Virus Infection. J. Virol. 2005, 79, 6441-6448. [CrossRef]

63. Crowe, C.R.; Chen, K.; Pociask, D.A.; Alcorn, J.F.; Krivich, C.; Enelow, R.I.; Ross, T.M.; Witztum, J.L.; Kolls, J.K. Critical Role of IL-17RA in Immunopathology of Influenza Infection. J. Immunol. 2009, 183, 5301-5310. [CrossRef] [PubMed]

64. Fernandes, I.G.; de Brito, C.A.; dos Reis, V.M.S.; Sato, M.N.; Pereira, N.Z. SARS-CoV-2 and Other Respiratory Viruses: What Does Oxidative Stress Have to Do with It? Oxid. Med. Cell. Longev. 2020, 2020. [CrossRef]

65. Hosakote, Y.M.; Liu, T.; Castro, S.M.; Garofalo, R.P.; Casola, A. Respiratory Syncytial Virus Induces Oxidative Stress by Modulating Antioxidant Enzymes. Am. J. Respir. Cell Mol. Biol. 2009, 41, 348-357. [CrossRef] [PubMed]

66. LeVine, A.M.; Elliott, J.; Whitsett, J.A.; Srikiatkhachorn, A.; Crouch, E.; DeSilva, N.; Korfhagen, T. Surfactant Protein-D Enhances Phagocytosis and Pulmonary Clearance of Respiratory Syncytial Virus. Am. J. Respir. Cell Mol. Biol. 2004, 31, 193-199. [CrossRef]

67. Hartshorn, K.L.; White, M.R.; Tecle, T.; Holmskov, U.; Crouch, E.C. Innate Defense against Influenza A Virus: Activity of Human Neutrophil Defensins and Interactions of Defensins with Surfactant Protein D. J. Immunol. 2006, 176, 6962-6972. [CrossRef] [PubMed]

68. Mayadas, T.N.; Cullere, X.; Lowell, C.A. The Multifaceted Functions of Neutrophils. Annu. Rev. Pathol. 2014, 9, 181-218. [CrossRef]

69. Li, M.; Zhao, L.; Liu, J.; Liu, A.; Jia, C.; Ma, D.; Jiang, Y.; Bai, X. Multi-Mechanisms Are Involved in Reactive Oxygen Species Regulation of mTORC1 Signaling. Cell. Signal. 2010, 22, 1469-1476. [CrossRef]

70. Tilton, C.; Clippinger, A.J.; Maguire, T.; Alwine, J.C. Human Cytomegalovirus Induces Multiple Means to Combat Reactive Oxygen Species. J. Virol. 2011, 85, 12585-12593. [CrossRef]

71. Hashimoto, Y.; Moki, T.; Takizawa, T.; Shiratsuchi, A.; Nakanishi, Y. Evidence for Phagocytosis of Influenza Virus-Infected, Apoptotic Cells by Neutrophils and Macrophages in Mice. J. Immunol. 2007, 178, 2448-2457. [CrossRef]

72. Idilman, R.; Cetinkaya, H.; Savaş, I.; Aslan, N.; Sak, S.D.; Baştemir, M.; Sarioğlu, M.; Soykan, I.; Bozdayi, M.; Colantoni, A.; et al. Bronchoalveolar Lavage Fluid Analysis in Individuals with Chronic Hepatitis C. J. Med. Virol. 2002, 66, 34-39. [CrossRef]

73. Leber, B.; Balázs, I.; Horvath, A.; Posch, A.; Streit, A.; Spindelböck, W.; Feldbacher, N.; Stiegler, P.; Stauber, R.E.; Rechberger, G.N.; et al. Direct Acting Antiviral Therapy Rescues Neutrophil Dysfunction and Reduces Hemolysis in Hepatitis C Infection. Transl. Res. 2021, 232, 103-114. [CrossRef]

74. Kozik, J.-H.; Trautmann, T.; Carambia, A.; Preti, M.; Lütgehetmann, M.; Krech, T.; Wiegard, C.; Heeren, J.; Herkel, J. Attenuated Viral Hepatitis in Trem1-/- Mice Is Associated with Reduced Inflammatory Activity of Neutrophils. Sci. Rep. 2016, 6, 28556. [CrossRef]

75. Veras, F.P.; Pontelli, M.C.; Silva, C.M.; Toller-Kawahisa, J.E.; de Lima, M.; Nascimento, D.C.; Schneider, A.H.; Caetité, D.; Tavares, L.A.; Paiva, I.M.; et al. SARS-CoV-2-triggered Neutrophil Extracellular Traps Mediate COVID-19 Pathology. J. Exp. Med. 2020, 217. [CrossRef]

76. Saitoh, T.; Komano, J.; Saitoh, Y.; Misawa, T.; Takahama, M.; Kozaki, T.; Uehata, T.; Iwasaki, H.; Omori, H.; Yamaoka, S.; et al. Neutrophil Extracellular Traps Mediate a Host Defense Response to Human Immunodeficiency Virus-1. Cell Host Microbe 2012, 12, 109-116. [CrossRef] [PubMed]

77. Daigo, K.; Hamakubo, T. Host-Protective Effect of Circulating Pentraxin 3 (PTX3) and Complex Formation with Neutrophil Extracellular Traps. Front. Immunol. 2012, 3, 378. [CrossRef] [PubMed]

78. Barr, F.D.; Ochsenbauer, C.; Wira, C.R.; Rodriguez-Garcia, M. Neutrophil Extracellular Traps Prevent HIV Infection in the Female Genital Tract. Mucosal Immunol. 2018, 11, 1420-1428. [CrossRef]

79. Viral Hemorrhagic Fevers (VHFs). Available online: https://www.cdc.gov/vhf/index.html (accessed on 17 June 2021).

80. Bray, M. Pathogenesis of Viral Hemorrhagic Fever. Curr. Opin. Immunol. 2005, 17, 399-403. [CrossRef] [PubMed]

81. LeDuc, J.W. Epidemiology of Hemorrhagic Fever Viruses. Rev. Infect. Dis. 1989, 11 (Suppl. 4), S730-S735. [CrossRef]

82. Guerrero, D.; Cantaert, T.; Missé, D. Aedes Mosquito Salivary Components and Their Effect on the Immune Response to Arboviruses. Front. Cell. Infect. Microbiol. 2020, 10, 407. [CrossRef] [PubMed]

83. Pingen, M.; Bryden, S.R.; Pondeville, E.; Schnettler, E.; Kohl, A.; Merits, A.; Fazakerley, J.K.; Graham, G.J.; McKimmie, C.S. Host Inflammatory Response to Mosquito Bites Enhances the Severity of Arbovirus Infection. Immunity 2016, 44, 1455-1469. [CrossRef]

84. Stegelmeier, A.A.; van Vloten, J.P.; Mould, R.C.; Klafuric, E.M.; Minott, J.A.; Wootton, S.K.; Bridle, B.W.; Karimi, K. Myeloid Cells during Viral Infections and Inflammation. Viruses 2019, 11, 168. [CrossRef] 
85. Findlay, J.S.; Ulaeto, D.; D’Elia, R.V. Cytokines and Viral Hemorrhagic Fever: Potential for Therapeutic Intervention. Future Virol. 2015, 10, 547-557. [CrossRef]

86. Messaoudi, I.; Basler, C.F. Immunological Features Underlying Viral Hemorrhagic Fevers. Curr. Opin. Immunol. 2015, 36, 38-46. [CrossRef] [PubMed]

87. Schulz, C.; Gabriel, G.; von Köckritz-Blickwede, M. Detrimental Role of Neutrophil Extracellular Traps during Dengue Virus Infection. Trends Immunol. 2020, 41, 3-6. [CrossRef] [PubMed]

88. Opasawatchai, A.; Amornsupawat, P.; Jiravejchakul, N.; Chan-In, W.; Spoerk, N.J.; Manopwisedjaroen, K.; Singhasivanon, P.; Yingtaweesak, T.; Suraamornkul, S.; Mongkolsapaya, J.; et al. Neutrophil Activation and Early Features of NET Formation Are Associated with Dengue Virus Infection in Human. Front. Immunol. 2018, 9, 3007. [CrossRef]

89. Hoang, L.T.; Lynn, D.J.; Henn, M.; Birren, B.W.; Lennon, N.J.; Le, P.T.; Duong, K.T.H.; Nguyen, T.T.H.; Mai, L.N.; Farrar, J.J.; et al. The Early Whole-Blood Transcriptional Signature of Dengue Virus and Features Associated with Progression to Dengue Shock Syndrome in Vietnamese Children and Young Adults. J. Virol. 2010, 84, 12982-12994. [CrossRef]

90. Thein, T.-L.; Lye, D.C.; Leo, Y.-S.; Wong, J.G.X.; Hao, Y.; Wilder-Smith, A. Severe Neutropenia in Dengue Patients: Prevalence and Significance. Am. J. Trop. Med. Hyg. 2014, 90, 984-987. [CrossRef]

91. Turtle, L.; Griffiths, M.J.; Solomon, T. Encephalitis Caused by Flaviviruses. QJM Int. J. Med. 2012, 105, $219-223$. [CrossRef] [PubMed]

92. Meyding-Lamadé, U.; Craemer, E.; Schnitzler, P. Emerging and Re-Emerging Viruses Affecting the Nervous System. Neurol. Res. Pract. 2019, 1, 20. [CrossRef]

93. Salimi, H.; Cain, M.D.; Klein, R.S. Encephalitic Arboviruses: Emergence, Clinical Presentation, and Neuropathogenesis. Neurotherapeutics 2016, 13, 514-534. [CrossRef] [PubMed]

94. Moore, S.M. The Current Burden of Japanese Encephalitis and the Estimated Impacts of Vaccination: Combining Estimates of the Spatial Distribution and Transmission Intensity of a Zoonotic Pathogen. medRxiv 2021. [CrossRef]

95. Marques, R.E.; Del Sarto, J.L.; Rocha, R.P.F.; Gomes, G.F.; Cramer, A.; Rachid, M.A.; Souza, D.G.; Nogueira, M.L.; Teixeira, M.M. Development of a Model of Saint Louis Encephalitis Infection and Disease in Mice. J. Neuroinflamm. 2017, 14, 61. [CrossRef]

96. Richner, J.M.; Gmyrek, G.B.; Govero, J.; Tu, Y.; van der Windt, G.J.W.; Metcalf, T.U.; Haddad, E.K.; Textor, J.; Miller, M.J.; Diamond, M.S. Age-Dependent Cell Trafficking Defects in Draining Lymph Nodes Impair Adaptive Immunity and Control of West Nile Virus Infection. PLoS Pathog. 2015, 11, e1005027. [CrossRef]

97. Ryan, E.T.; Hill, D.R.; Solomon, T.; Aronson, N.E.; Endy, T.P. (Eds.) 38-Viral CNS Infections. In Hunter's Tropical Medicine and Emerging Infectious Diseases, 10th ed.; Elsevier: London, UK, 2020; pp. 382-420, ISBN 9780323555128.

98. Rocha, R.F.; Del Sarto, J.L.; Gomes, G.F.; Gonçalves, M.P.; Rachid, M.A.; Smetana, J.H.C.; Souza, D.G.; Teixeira, M.M.; Marques, R.E. Type I Interferons Are Essential While Type II Interferon Is Dispensable for Protection against St. Louis Encephalitis Virus Infection in the Mouse Brain. Virulence 2021, 12, 244-259. [CrossRef] [PubMed]

99. Redant, V.; Favoreel, H.W.; Dallmeier, K.; Van Campe, W.; De Regge, N. Efficient Control of Japanese Encephalitis Virus in the Central Nervous System of Infected Pigs Occurs in the Absence of a Pronounced Inflammatory Immune Response. J. Neuroinflamm. 2020, 17, 315. [CrossRef] [PubMed]

100. Bardina, S.V.; Lim, J.K. The Role of Chemokines in the Pathogenesis of Neurotropic Flaviviruses. Immunol. Res. 2012, 54, 121-132. [CrossRef]

101. Lannes, N.; Summerfield, A.; Filgueira, L. Regulation of Inflammation in Japanese Encephalitis. J. Neuroinflamm. 2017, 14, 158. [CrossRef] [PubMed]

102. Su, Q.; Xie, Z.-X.; He, F.; Liu, Z.-C.; Song, X.-J.; Zhao, F.-C.; Li, D.; Che, F.-Y. Adults with Severe Japanese Encephalitis: A Retrospective Analysis of 9 Cases in Linyi, China. Neurol. Sci. 2020. [CrossRef]

103. Singh, S.; Singh, G.; Tiwari, S.; Kumar, A. CCR2 Inhibition Reduces Neurotoxic Microglia Activation Phenotype After Japanese Encephalitis Viral Infection. Front. Cell. Neurosci. 2020, 14, 230. [CrossRef]

104. Singh, A.; Kulshreshtha, R.; Mathur, A. Secretion of the Chemokine Interleukin-8 during Japanese Encephalitis Virus Infection. J. Med. Microbiol. 2000, 49, 607-612. [CrossRef]

105. Srivastava, S.; Khanna, N.; Saxena, S.K.; Singh, A.; Mathur, A.; Dhole, T.N. Degradation of Japanese Encephalitis Virus by Neutrophils. Int. J. Exp. Pathol. 1999, 80, 17-24. [CrossRef]

106. Debiasi, R.L.; Tyler, K.L. West Nile Virus Meningoencephalitis. Nat. Clin. Pract. Neurol. 2006, 2, 264-275. [CrossRef]

107. Bai, F.; Kong, K.-F.; Dai, J.; Qian, F.; Zhang, L.; Brown, C.R.; Fikrig, E.; Montgomery, R.R. A Paradoxical Role for Neutrophils in the Pathogenesis of West Nile Virus. J. Infect. Dis. 2010, 202, 1804-1812. [CrossRef] [PubMed]

108. Paul, A.M.; Acharya, D.; Duty, L.; Thompson, E.A.; Le, L.; Stokic, D.S.; Leis, A.A.; Bai, F. Osteopontin Facilitates West Nile Virus Neuroinvasion via Neutrophil "Trojan Horse" Transport. Sci. Rep. 2017, 7, 1-11. [CrossRef] [PubMed]

109. Macdonald, F. Murray Valley Encephalitis Infection in the Laboratory Mouse. I. Influence of Age on Susceptibility to Infection. Aust. J. Exp. Biol. Med. Sci. 1952, 30, 319-324. [CrossRef]

110. Andrews, D.M.; Matthews, V.B.; Sammels, L.M.; Carrello, A.C.; McMinn, P.C. The Severity of Murray Valley Encephalitis in Mice Is Linked to Neutrophil Infiltration and Inducible Nitric Oxide Synthase Activity in the Central Nervous System. J. Virol. 1999, 73, 8781-8790. [CrossRef]

111. McMinn, P.C.; Dalgarno, L.; Weir, R.C. A Comparison of the Spread of Murray Valley Encephalitis Viruses of High or Low Neuroinvasiveness in the Tissues of Swiss Mice after Peripheral Inoculation. Virology 1996, 220, 414-423. [CrossRef] [PubMed] 
112. Matthews, V.; Robertson, T.; Kendrick, T.; Abdo, M.; Papadimitriou, J.; McMinn, P. Morphological Features of Murray Valley Encephalitis Virus Infection in the Central Nervous System of Swiss Mice. Int. J. Exp. Pathol. 2000, 81, 31-40. [CrossRef]

113. Hombach, J.; Barrett, A.D.T.; Kollaritsch, H. 59-Tickborne Encephalitis Vaccines. In Plotkin's Vaccines, 7th ed.; Plotkin, S.A., Orenstein, W.A., Offit, P.A., Edwards, K.M., Eds.; Elsevier: Amsterdam, The Netherlands, 2018; pp. 1080-1094.e5. ISBN 9780323357616 .

114. Calvert, A.; Quenby, M.; Heath, P.T. Chapter 9-Vaccination in pregnancy in specific circumstances. In Maternal Immunization; Leuridan, E.E., Nunes, M.C., Jones, C.E., Eds.; Academic Press: Cambridge, MA, USA, 2020; pp. 191-210. ISBN 9780128145821.

115. Plekhova, N.G.; Somova, L.M.; Lyapun, I.N.; Krylova, N.V.; Leonova, G.N. Neutrophil Apoptosis Induction by Tick-Borne Encephalitis Virus. Bull. Exp. Biol. Med. 2012, 153, 105-108. [CrossRef] [PubMed]

116. Thangamani, S.; Hermance, M.E.; Santos, R.I.; Slovak, M.; Heinze, D.; Widen, S.G.; Kazimirova, M. Transcriptional Immunoprofiling at the Tick-Virus-Host Interface during Early Stages of Tick-Borne Encephalitis Virus Transmission. Front. Cell. Infect. Microbiol. 2017, 7, 494. [CrossRef] [PubMed]

117. Wilson, J.G. Experimental Studies on Congenital Malformations. J. Chronic Dis. 1959, 10, 111-130. [CrossRef]

118. Barlow, S. Handbook of Teratology, Volume 1: General Principles and Etiology. Biochem. Soc. Trans. 1978, 6, 473-474. [CrossRef]

119. Alwan, S.; Chambers, C.D. Identifying Human Teratogens: An Update. J. Pediatr. Genet. 2015, 4, 39-41. [CrossRef]

120. Nausheen, F.; Bashir, S.S.; Atapattu, D.N. Pregnancy Associated Arbovirus Infections. Clin. Microbiol. Infect. 2018, 3, 1-9. [CrossRef]

121. Coyne, C.B.; Lazear, H.M. Zika Virus-Reigniting the TORCH. Nat. Rev. Microbiol. 2016, 14, 707-715. [CrossRef] [PubMed]

122. Ander, S.E.; Diamond, M.S.; Coyne, C.B. Immune Responses at the Maternal-Fetal Interface. Sci. Immunol. 2019, 4. [CrossRef]

123. Mor, G.; Aldo, P.; Alvero, A.B. The Unique Immunological and Microbial Aspects of Pregnancy. Nat. Rev. Immunol. 2017, 17, 469-482. [CrossRef]

124. Abu-Raya, B.; Michalski, C.; Sadarangani, M.; Lavoie, P.M. Maternal Immunological Adaptation during Normal Pregnancy. Front. Immunol. 2020, 11, 575197. [CrossRef]

125. Kourtis, A.P.; Read, J.S.; Jamieson, D.J. Pregnancy and Infection. N. Engl. J. Med. 2014, 370, 2211-2218. [CrossRef]

126. Morelli, S.S.; Mandal, M.; Goldsmith, L.T.; Kashani, B.N.; Ponzio, N.M. The Maternal Immune System during Pregnancy and Its Influence on Fetal Development. Res. Rep. Biol. 2015, 6, 171-189. [CrossRef]

127. Thomson, A.J.; Telfer, J.F.; Young, A.; Campbell, S.; Stewart, C.J.; Cameron, I.T.; Greer, I.A.; Norman, J.E. Leukocytes Infiltrate the Myometrium during Human Parturition: Further Evidence That Labour Is an Inflammatory Process. Hum. Reprod. 1999, 14, 229-236. [CrossRef]

128. Gomez-Lopez, N.; Guilbert, L.J.; Olson, D.M. Invasion of the Leukocytes into the Fetal-Maternal Interface during Pregnancy. J. Leukoc. Biol. 2010, 88, 625-633. [CrossRef]

129. Kruse, A.; Martens, N.; Fernekorn, U.; Hallmann, R.; Butcher, E.C. Alterations in the Expression of Homing-Associated Molecules at the Maternal/fetal Interface during the Course of Pregnancy. Biol. Reprod. 2002, 66, 333-345. [CrossRef]

130. Sacks, G.P.; Studena, K.; Sargent, K.; Redman, C.W. Normal Pregnancy and Preeclampsia Both Produce Inflammatory Changes in Peripheral Blood Leukocytes Akin to Those of Sepsis. Am. J. Obstet. Gynecol. 1998, 179, 80-86. [CrossRef]

131. Giaglis, S.; Stoikou, M.; Sur Chowdhury, C.; Schaefer, G.; Grimolizzi, F.; Rossi, S.W.; Hoesli, I.M.; Lapaire, O.; Hasler, P.; Hahn, S. Multimodal Regulation of NET Formation in Pregnancy: Progesterone Antagonizes the Pro-NETotic Effect of Estrogen and G-CSF. Front. Immunol. 2016, 7, 565. [CrossRef]

132. Wira, C.R.; Fahey, J.V.; Rodriguez-Garcia, M.; Shen, Z.; Patel, M.V. Regulation of Mucosal Immunity in the Female Reproductive Tract: The Role of Sex Hormones in Immune Protection against Sexually Transmitted Pathogens. Am. J. Reprod. Immunol. 2014, 72, 236-258. [CrossRef] [PubMed]

133. Li, S.; Herrera, G.G.; Tam, K.K.; Lizarraga, J.S.; Beedle, M.-T.; Winuthayanon, W. Estrogen Action in the Epithelial Cells of the Mouse Vagina Regulates Neutrophil Infiltration and Vaginal Tissue Integrity. Sci. Rep. 2018, 8, 11247. [CrossRef]

134. Aagaard-Tillery, K.M.; Silver, R.; Dalton, J. Immunology of Normal Pregnancy. Semin. Fetal Neonatal Med. 2006, 11, $279-295$. [CrossRef] [PubMed]

135. Shimoya, K.; Matsuzaki, N.; Taniguchi, T.; Kameda, T.; Koyama, M.; Neki, R.; Saji, F.; Tanizawa, O. Human Placenta Constitutively Produces Interleukin-8 during Pregnancy and Enhances Its Production in Intrauterine Infection. Biol. Reprod. 1992, 47, 220-226. [CrossRef] [PubMed]

136. Gomez-Lopez, N.; Romero, R.; Xu, Y.; Leng, Y.; Garcia-Flores, V.; Miller, D.; Jacques, S.M.; Hassan, S.S.; Faro, J.; Alsamsam, A.; et al. Are Amniotic Fluid Neutrophils in Women with Intraamniotic Infection And/or Inflammation of Fetal or Maternal Origin? Am. J. Obstet. Gynecol. 2017, 217, 693.e1-693.e16. [CrossRef] [PubMed]

137. Szarka, A.; Rigó, J., Jr.; Lázár, L.; Beko, G.; Molvarec, A. Circulating Cytokines, Chemokines and Adhesion Molecules in Normal Pregnancy and Preeclampsia Determined by Multiplex Suspension Array. BMC Immunol. 2010, 11, 59. [CrossRef] [PubMed]

138. Gupta, A.K.; Hasler, P.; Holzgreve, W.; Gebhardt, S.; Hahn, S. Induction of Neutrophil Extracellular DNA Lattices by Placental Microparticles and IL-8 and Their Presence in Preeclampsia. Hum. Immunol. 2005, 66, 1146-1154. [CrossRef]

139. Vokalova, L.; van Breda, S.V.; Ye, X.L.; Huhn, E.A.; Than, N.G.; Hasler, P.; Lapaire, O.; Hoesli, I.; Rossi, S.W.; Hahn, S. Excessive Neutrophil Activity in Gestational Diabetes Mellitus: Could It Contribute to the Development of Preeclampsia? Front. Endocrinol. 2018, 9, 542. [CrossRef] [PubMed]

140. Staples, J.E.; Monath, T.P. Yellow Fever: 100 Years of Discovery. JAMA 2008, 300, 960-962. [CrossRef] 
141. Machado, C.R.; Machado, E.S.; Rohloff, R.D.; Azevedo, M.; Campos, D.P.; de Oliveira, R.B.; Brasil, P. Is Pregnancy Associated with Severe Dengue? A Review of Data from the Rio de Janeiro Surveillance Information System. PLoS Negl. Trop. Dis. 2013, 7, e2217. [CrossRef]

142. Tan, P.C.; Soe, M.Z.; Si Lay, K.; Wang, S.M.; Sekaran, S.D.; Omar, S.Z. Dengue Infection and Miscarriage: A Prospective Case Control Study. PLoS Negl. Trop. Dis. 2012, 6, e1637. [CrossRef] [PubMed]

143. Paixão, E.S.; Teixeira, M.G.; Costa, M.d.C.N.; Rodrigues, L.C. Dengue during Pregnancy and Adverse Fetal Outcomes: A Systematic Review and Meta-Analysis. Lancet Infect. Dis. 2016, 16, 857-865. [CrossRef]

144. Sirinavin, S.; Nuntnarumit, P.; Supapannachart, S.; Boonkasidecha, S.; Techasaensiri, C.; Yoksarn, S. Vertical Dengue Infection: Case Reports and Review. Pediatr. Infect. Dis. J. 2004, 23, 1042-1047. [CrossRef] [PubMed]

145. Basurko, C.; Carles, G.; Youssef, M.; Guindi, W.E.L. Maternal and Fetal Consequences of Dengue Fever during Pregnancy. Eur. J. Obstet. Gynecol. Reprod. Biol. 2009, 147, 29-32. [CrossRef]

146. Sicé, A.; Rodallec, C. Manifestations Hémorragiques de: La Fièvre Jaune (typhus Amaril). Répercussions de L'infection Maternelle Sur L'organisme Foetal. Bull. Soc. Pathol. Exot. 1940, 33, 66-69.

147. Bentlin, M.R.; de Barros Almeida, R.A.M.; Coelho, K.I.R.; Ribeiro, A.F.; Siciliano, M.M.; Suzuki, A.; Fortaleza, C.M.C.B. Perinatal Transmission of Yellow Fever, Brazil, 2009. Emerg. Infect. Dis. 2011, 17, 1779-1780. [CrossRef]

148. Burns, K.F. Congenital Japanese B Encephalitis Infection of Swine. Proc. Soc. Exp. Biol. Med. 1950, 75, 621-625. [CrossRef] [PubMed]

149. Shimizu, T.; Kawakami, Y.; Fukuhara, S.; Matumoto, M. Experimental Stillbirth in Pregnant Swine Infected with Japanese Encephalitis Virus. Jpn. J. Exp. Med. 1954, 24, 363-375.

150. Chaturvedi, U.C.; Mathur, A.; Chandra, A.; Das, S.K.; Tandon, H.O.; Singh, U.K. Transplacental Infection with Japanese Encephalitis Virus. J. Infect. Dis. 1980, 141, 712-715. [CrossRef]

151. Andersen, A.A.; Hanson, R.P. Experimental Transplacental Transmission of St. Louis Encephalitis Virus in Mice. Infect. Immun. 1970, 2, 320-325. [CrossRef] [PubMed]

152. Charlier, C.; Beaudoin, M.-C.; Couderc, T.; Lortholary, O.; Lecuit, M. Arboviruses and Pregnancy: Maternal, Fetal, and Neonatal Effects. Lancet Child Adolesc. Health 2017, 1, 134-146. [CrossRef]

153. Centers for Disease Control and Prevention (CDC). Intrauterine West Nile Virus Infection-New York, 2002. MMWR Morb. Mortal. Wkly. Rep. 2002, 51, 1135-1136.

154. Alpert, S.G.; Fergerson, J.; Noël, L.P. Intrauterine West Nile Virus: Ocular and Systemic Findings. Am. J. Ophthalmol. 2003, 136, 733-735. [CrossRef]

155. O'Leary, D.R.; Kuhn, S.; Kniss, K.L.; Hinckley, A.F.; Rasmussen, S.A.; Pape, W.J.; Kightlinger, L.K.; Beecham, B.D.; Miller, T.K.; Neitzel, D.F.; et al. Birth Outcomes Following West Nile Virus Infection of Pregnant Women in the United States: $2003-2004$. Pediatrics 2006, 117, e537-e545. [CrossRef]

156. Platt, D.J.; Smith, A.M.; Arora, N.; Diamond, M.S.; Coyne, C.B.; Miner, J.J. Zika Virus-Related Neurotropic Flaviviruses Infect Human Placental Explants and Cause Fetal Demise in Mice. Sci. Transl. Med. 2018, 10. [CrossRef]

157. Morrison, T.E.; Diamond, M.S. Animal Models of Zika Virus Infection, Pathogenesis, and Immunity. J. Virol. 2017, 91, e00009-17. [CrossRef] [PubMed]

158. Brasil, P.; Pereira, J.P., Jr.; Moreira, M.E.; Ribeiro Nogueira, R.M.; Damasceno, L.; Wakimoto, M.; Rabello, R.S.; Valderramos, S.G.; Halai, U.-A.; Salles, T.S.; et al. Zika Virus Infection in Pregnant Women in Rio de Janeiro. N. Engl. J. Med. 2016, 375, $2321-2334$. [CrossRef] [PubMed]

159. Schuler-Faccini, L.; Ribeiro, E.M.; Feitosa, I.M.L.; Horovitz, D.D.G.; Cavalcanti, D.P.; Pessoa, A.; Doriqui, M.J.R.; Neri, J.I.; Monteiro de Pina Neto, J.; Wanderley, H.Y.C.; et al. Possible Association Between Zika Virus Infection and Microcephaly-Brazil, 2015. MMWR Morb. Mortal. Wkly. Rep. 2016, 65, 59-62. [CrossRef] [PubMed]

160. Leal, M.C.; Muniz, L.F.; Ferreira, T.S.A.; Santos, C.M.; Almeida, L.C.; Van Der Linden, V.; Ramos, R.C.F.; Rodrigues, L.C.; Neto, S.S.C. Hearing Loss in Infants with Microcephaly and Evidence of Congenital Zika Virus Infection-Brazil, November 2015-May 2016. MMWR Morb. Mortal. Wkly. Rep. 2016, 65, 917-919. [CrossRef] [PubMed]

161. Camacho-Zavala, E.; Santacruz-Tinoco, C.; Muñoz, E.; Chacón-Salinas, R.; Salazar-Sanchez, M.I.; Grajales, C.; González-Ibarra, J.; Borja-Aburto, V.H.; Jaenisch, T.; Gonzalez-Bonilla, C.R. Pregnant Women Infected with Zika Virus Show Higher Viral Load and Immunoregulatory Cytokines Profile with CXCL10 Increase. Viruses 2021, 13, 80. [CrossRef]

162. Ornelas, A.M.M.; Pezzuto, P.; Silveira, P.P.; Melo, F.O.; Ferreira, T.A.; Oliveira-Szejnfeld, P.S.; Leal, J.I.; Amorim, M.M.R.; Hamilton, S.; Rawlinson, W.D.; et al. Immune Activation in Amniotic Fluid from Zika Virus-Associated Microcephaly. Ann. Neurol. 2017, 81, 152-156. [CrossRef]

163. Lima, M.C.; de Mendonça, L.R.; Rezende, A.M.; Carrera, R.M.; Aníbal-Silva, C.E.; Demers, M.; D'Aiuto, L.; Wood, J.; Chowdari, K.V.; Griffiths, M.; et al. The Transcriptional and Protein Profile from Human Infected Neuroprogenitor Cells Is Strongly Correlated to Zika Virus Microcephaly Cytokines Phenotype Evidencing a Persistent Inflammation in the CNS. Front. Immunol. 2019, 10, 1928. [CrossRef]

164. Khaiboullina, S.; Uppal, T.; Kletenkov, K.; St. Jeor, S.C.; Garanina, E.; Rizvanov, A.; Verma, S.C. Transcriptome Profiling Reveals Pro-Inflammatory Cytokines and Matrix Metalloproteinase Activation in Zika Virus Infected Human Umbilical Vein Endothelial Cells. Front. Pharmacol. 2019, 10, 642. [CrossRef] 
165. Bayer, A.; Lennemann, N.J.; Ouyang, Y.; Bramley, J.C.; Morosky, S.; Marques, E.T.D.A., Jr.; Cherry, S.; Sadovsky, Y.; Coyne, C.B. Type III Interferons Produced by Human Placental Trophoblasts Confer Protection against Zika Virus Infection. Cell Host Microbe 2016, 19, 705-712. [CrossRef]

166. Galani, I.E.; Triantafyllia, V.; Eleminiadou, E.-E.; Koltsida, O.; Stavropoulos, A.; Manioudaki, M.; Thanos, D.; Doyle, S.E.; Kotenko, S.V.; Thanopoulou, K.; et al. Interferon- $\lambda$ Mediates Non-Redundant Front-Line Antiviral Protection against Influenza Virus Infection without Compromising Host Fitness. Immunity 2017, 46, 875-890.e6. [CrossRef] [PubMed]

167. Blazek, K.; Eames, H.L.; Weiss, M.; Byrne, A.J.; Perocheau, D.; Pease, J.E.; Doyle, S.; McCann, F.; Williams, R.O.; Udalova, I.A IFN- $\lambda$ Resolves Inflammation via Suppression of Neutrophil Infiltration and IL-1 $\beta$ Production. J. Exp. Med. 2015, 212, 845-853. [CrossRef] [PubMed]

168. Azamor, T.; Torrentes-Carvalho, A.; Vasconcelos, Z.; Bom, A.P.D.A.; Melgaço, J.G. Innate Immunity Modulation during Zika Virus Infection on Pregnancy: What We Still Need to Know for Medical Sciences Breakthrough. In Cell Interaction; Singh, B., Ed.; IntechOpen: Rijeka, Croatia, 2021.

169. Azamor, T.; Cunha, D.P.; da Silva, A.M.V.; de Lima Bezerra, O.C.; Ribeiro-Alves, M.; Calvo, T.L.; de Souza Gomes Kehdy, F.; de Neves Manta, F.S.; Pinto, T.G.; Ferreira, L.P.; et al. Congenital Zika Syndrome Is Associated with Interferon Alfa Receptor 1. bioRxiv 2020, 715862. [CrossRef]

170. Yockey, L.J.; Jurado, K.A.; Arora, N.; Millet, A.; Rakib, T.; Milano, K.M.; Hastings, A.K.; Fikrig, E.; Kong, Y.; Horvath, T.L.; et al. Type I Interferons Instigate Fetal Demise after Zika Virus Infection. Sci. Immunol. 2018, 3. [CrossRef]

171. Iwasaki, A.; Pillai, P.S. Innate Immunity to Influenza Virus Infection. Nat. Rev. Immunol. 2014, 14, 315-328. [CrossRef]

172. Andrade, D.; Kim, M.; Blanco, L.P.; Karumanchi, S.A.; Koo, G.C.; Redecha, P.; Kirou, K.; Alvarez, A.M.; Mulla, M.J.; Crow, M.K.; et al. Interferon- $\alpha$ and Angiogenic Dysregulation in Pregnant Lupus Patients Who Develop Preeclampsia. Arthritis Rheumatol. 2015, 67, 977-987. [CrossRef] 